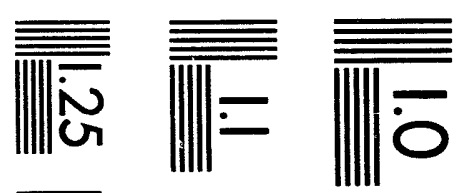

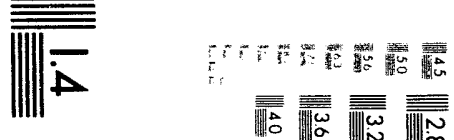

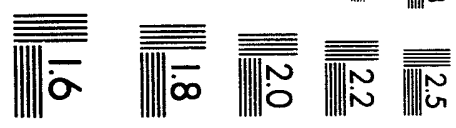



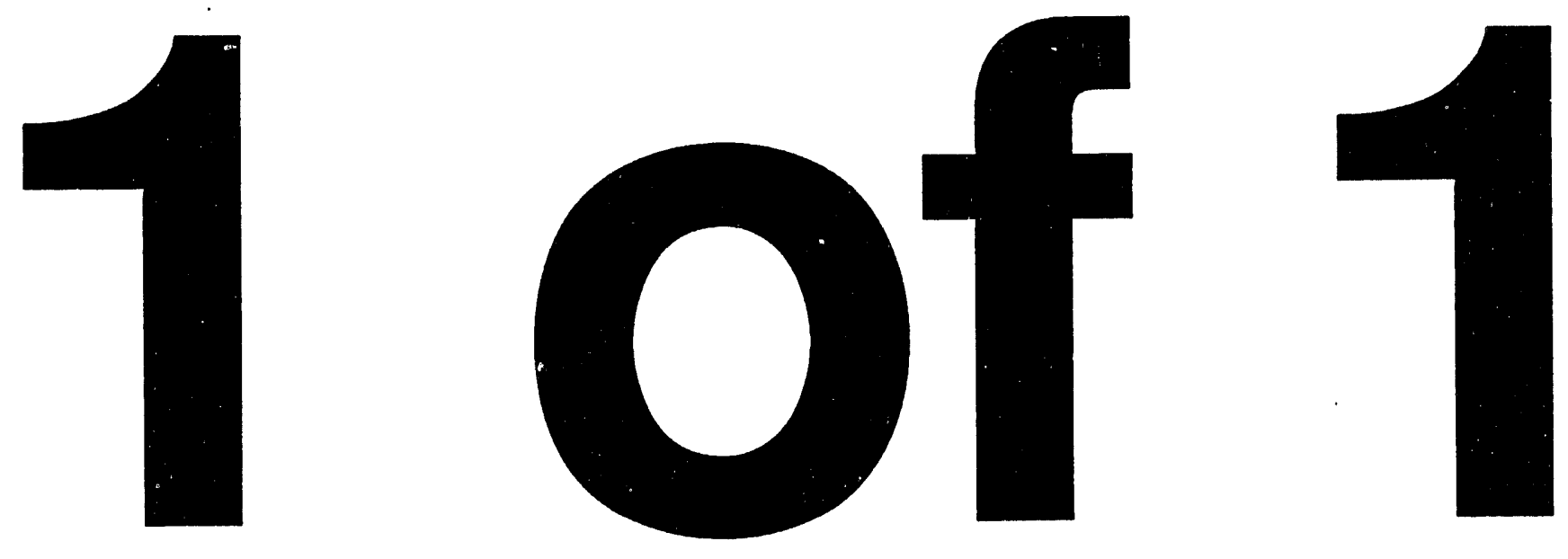


\title{
A WEATHERIZATION MANUAL \\ FOR LIHEAP POLICY MAKERS AND \\ PROGRAM ADMINISTRATORS
}

\author{
Marjorie J. Witherspoon* \\ Ron Marabate* \\ Melissa Weinhaus* \\ Joel F. Eisenberg** \\ September, 1993 \\ Report prepared by \\ **The Economic Opportunity Research Institute \\ and \\ *The National Association for State Community Services Programs \\ Under Subcontract 86X-SK904V \\ for \\ Administration for Children and Families \\ U.S. Department of Health and Human Services \\ and \\ Office of Energy Efficiency and Renewable Energy \\ U.S. Department of Energy \\ Oak Ridge National Laboratory \\ Managed by \\ Martin Marietta Energy Systems. Inc. \\ Under Contract No. DE-AC05-85OR21400 \\ for the \\ U.S. Department of Energy
}




\section{MATRIX OF SHOWCASE WEATHERIZATION PROGRAMS}

\begin{tabular}{|c|c|c|c|c|}
\hline PROGRAM & $\begin{array}{c}\text { Case } \\
\text { Management } \\
\text { Approach To } \\
\text { Client Services }\end{array}$ & $\begin{array}{c}\text { Chient } \\
\text { Education }\end{array}$ & $\begin{array}{l}\text { QA and } \\
\text { Inspection }\end{array}$ & $\begin{array}{l}\text { Other } \\
\text { Activities }\end{array}$ \\
\hline California & & $\mathrm{x}$ & $\mathrm{x}$ & $\mathrm{X}^{1}$ \\
\hline Colorado & & & $\mathrm{x}$ & \\
\hline Illinois & & & $\mathrm{x}$ & $X^{2}$ \\
\hline Massachusetts & & & & $x^{3}$ \\
\hline Minnesota & & $\mathrm{x}$ & & $\mathrm{X}^{4}$ \\
\hline New York & $\mathrm{X}$ & & & \\
\hline $\begin{array}{l}\text { Northern Tier } \\
\text { Community } \\
\text { Action Corp. }\end{array}$ & & $\mathrm{x}$ & & \\
\hline Washington & & & & $\mathrm{X}^{5}$ \\
\hline
\end{tabular}

1 Staff training.

2 Staff training, coordination with HOME funds.

3 Heating system repair and replacement program.

4 Heating system technician training.

5 Multiple funding sources integration. 


\section{TABLE OF CONTENTS}

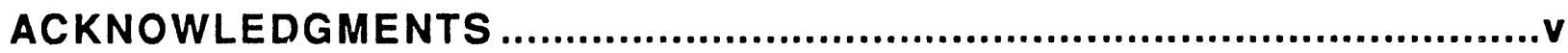

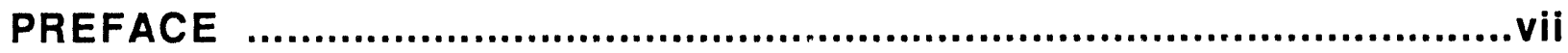

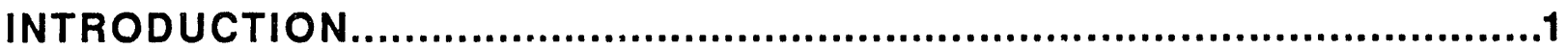

FEDERAL LOW-INCOME RESIDENTIAL ENERGY PROGRAMS ....................... 1

Low-Income Home Energy Assistance Program ....................................................

The DOE Low-Income Weatherization Program ......................................................2

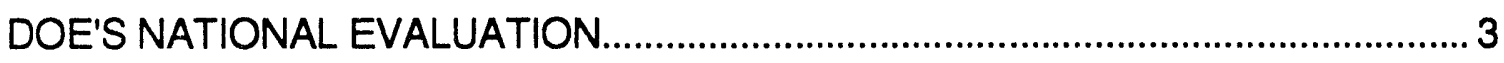

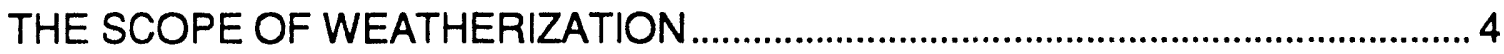

IDENTIFICATION OF INNOVATIVE PROGRAMS .................................................

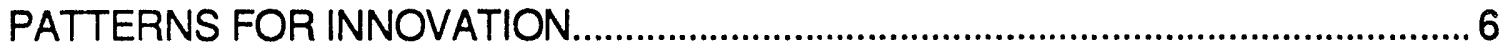

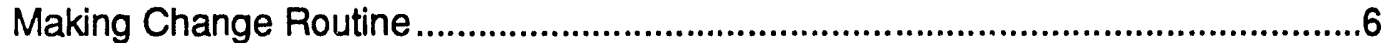

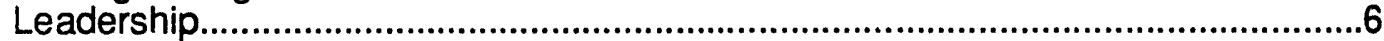

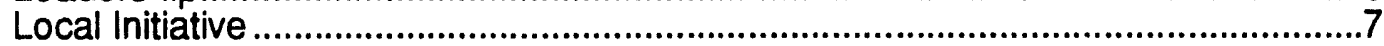

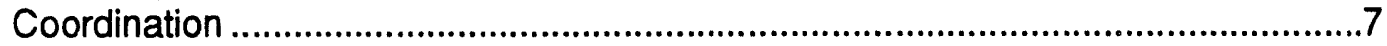

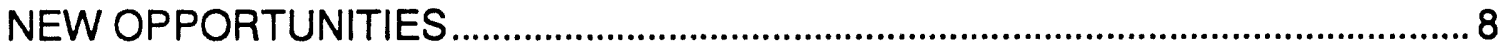

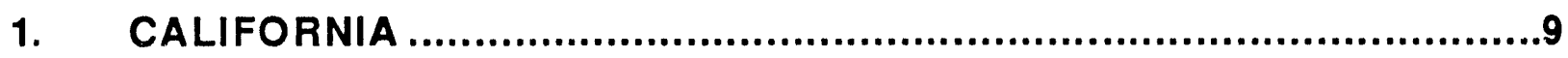

1.1 ADMINISTRATIVE STRUCTURE

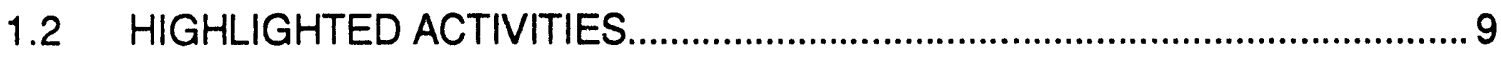

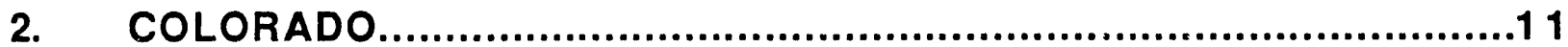

2.1 ADMINISTRATIVE STRUCTURE AND CLIENT REFERRAL ....................11

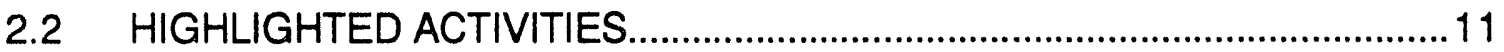

2.2.1 Targeting..................................................................................................11

2.2.2 Crisis Intervention ...............................................................................12

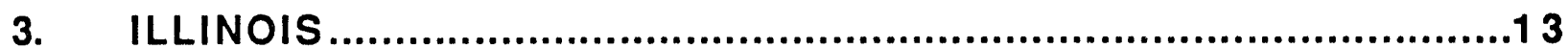

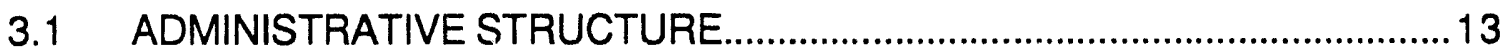

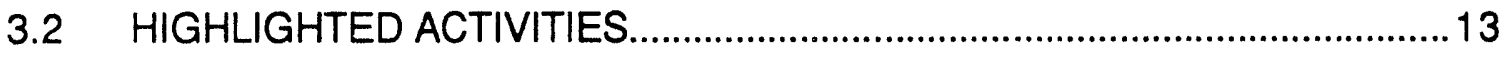

3.2.1 Furnace Work .......................................................................................

3.2.2 Coordination with HOME ......................................................................13

3.2.3 Staff Training and Certification..........................................................................14

3.2.4 Whole House Energy Audit.........................................................................15

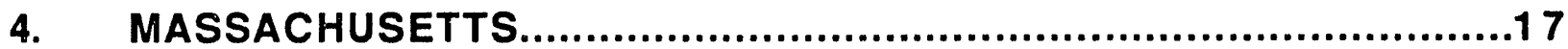

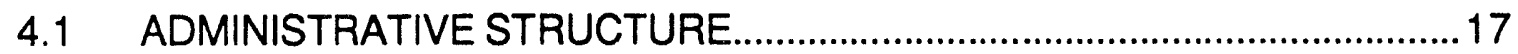

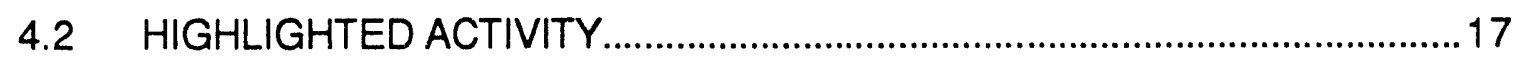




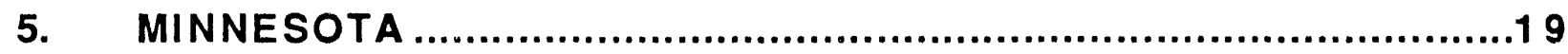

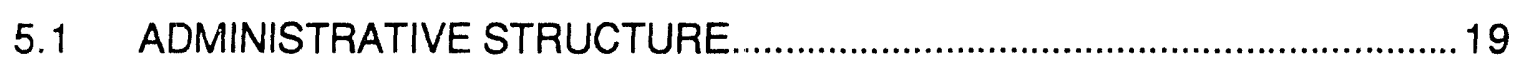

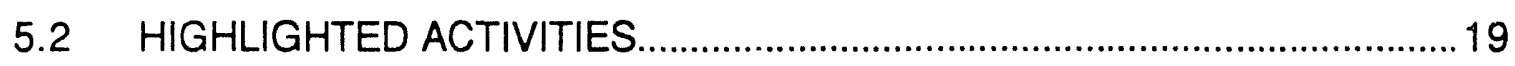

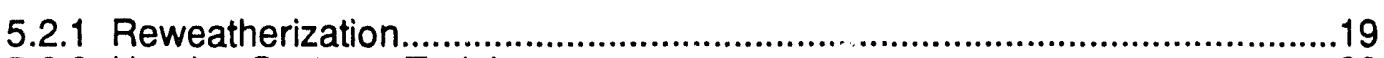

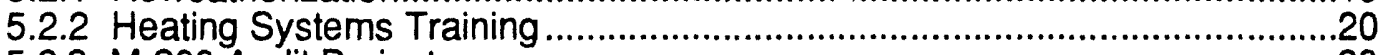

5.2.3 M-200 Audit Project....................................................................................20

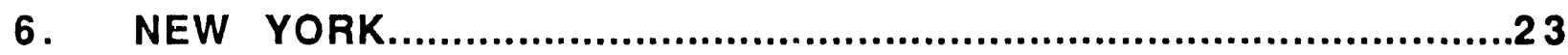

6.1 ADMINISTRATIVE STRUCTURE

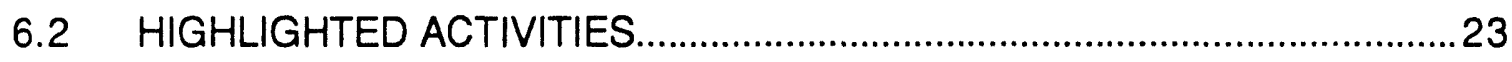

6.2.1 Heating System Service Coordination..................................................23

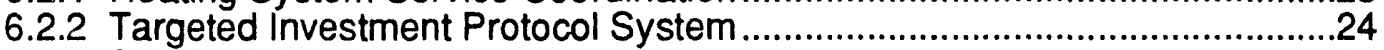

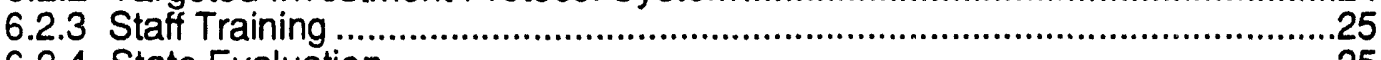

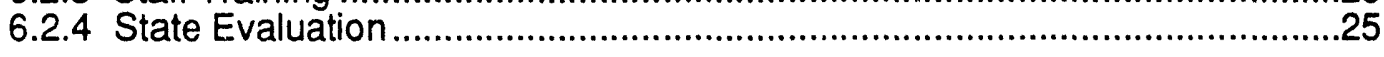

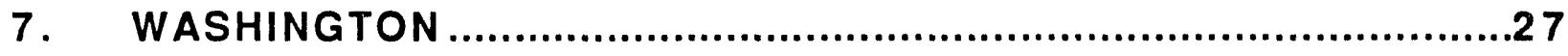

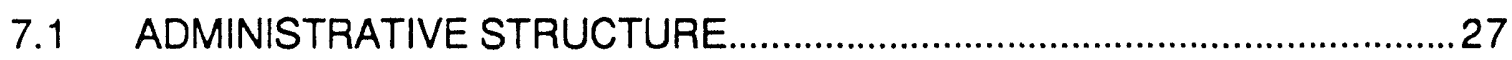

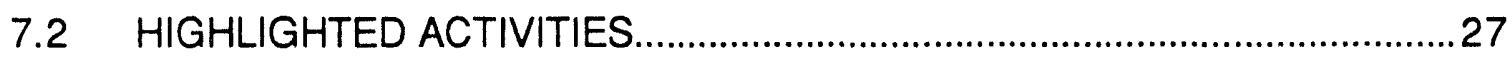

7.2.1 Coordination and Integration of Multiple Funding Sources ........................27

7.2.2 Consumer Education Pilot Project..............................................................29

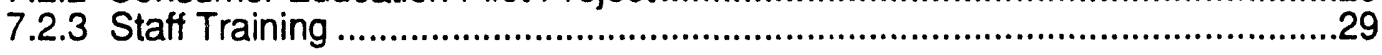

8. NORTHERN TIER COMMUNITY ACTION CORPORATION ..............31

8.1 ADMINISTRATIVE STRUCTURE ............................................................ 31

8.2 Highlighted Activities................................................................................. 31

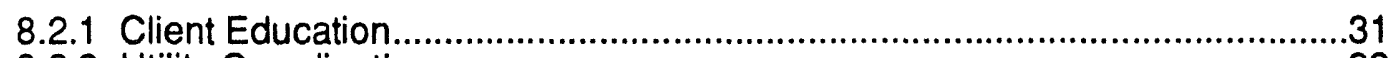

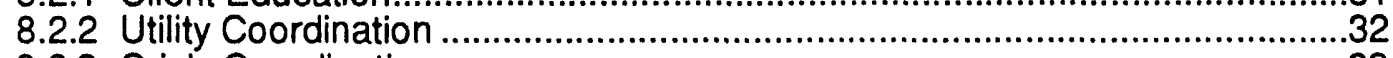

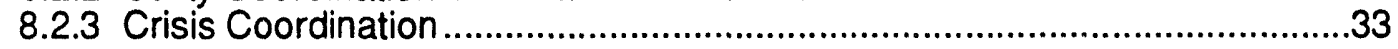

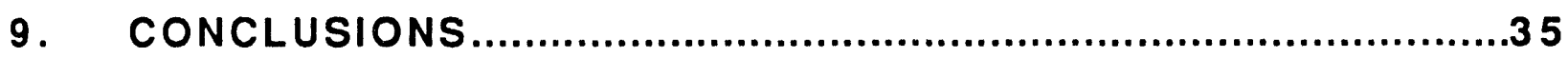

10. REFERENCES............................................................. 7

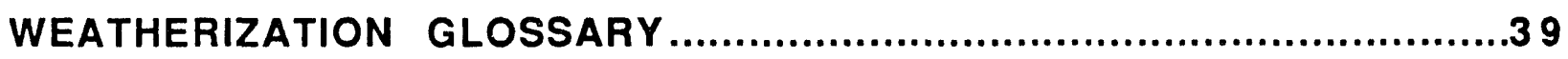

RECOMMENDED PUBLICATIONS AND RESOURCES.........................45

APPENDIX A - List of Showcase Programs

APPENDIX B - LIHEAP Information Memorandum 


\section{ACKNOWLEDGMENTS}

Many people have participated in the collection and preparation of materials for this handbook. The authors are grateful for their advice, comments, and suggestions, without which this report would not have been possible.

The authors would particularly like to acknowledge the contribution of the following persons who took time away from their jobs for telephone interviews and provided additional reports on their programs: Mike Micciche and Tony Curtis, California; Jeff Ackermann, Colorado; Wayne Curtis, Illinois, Ken Rauseo, Massachusetts; Mark Kaszynski, Minnesota; Rick Gerardi, New York; Kenneth Straub, Northern Tier Community Action Corporation, Pennsylvania; Kathy Kreiter, Washington, and Michael Karp, Opportunity Council, Washington.

In addition to the above individuals, this report was produced under guidance of Leon Litow of the U.S. Department of Health and Human Services and Marilyn Brown of Oak Ridge National Laboratory. 


\section{PREFACE}

This manual was developed to provide a broad overview of innovative and cost effective weatherization programming activities that are funded by Low-Income Home Energy Assistance Program (LIHEAP) block grant funds.

Since the inception of the federal block grant system in the early 1980's, states have had flexibility in how to utilize the federal funds allocated. With the LIHEAP funds, states were allowed to allocate up to 15 percent (now up to 25 percent with a waiver) of their total state allocation to weatherization and other energy-related home repairs, including energy conservation activities.

The goal of this document is to provide state LIHEAP administrators with a review of the current "world of weatherization," and to highlight several "showcase" programs that are presently operating innovatively with LIHEAP dollars. In many of the showcase examples, state and local administrators are coordinating the LIHEAP funds in creative and productive ways with the U.S. Department of Energy (DOE) Weatherization Assistance Program's funding, and with a variety of other federal, state, and utility company resources. This manual incorporates an extensive glossary, informative appendices and bibliography so that any LIHEAP administrator can easily familiarize him/herself with the most innovative weatherization programs across the country, plus have ready access to information about contact persons.

This manual was prepared under a subcontract from Oak Ridge National Laboratory by the National Association for State Community Services Programs (NASCSP). It was completed in conjunction with DOE's National Weatherization Evaluation. Major writing was done by Ron Marabate and Marjorie J. Wiiherspoon. The project was conducted under the guidance of Leon Litow of the U.S. Department of Health and Human Services' Division of Energy Assistance in the Administration for Children and Families, and Marilyn Brown of Oak Ridge National Laboratory. An extensive set of appendices are part of the full manual that was submitted to HHS. These appendices include detailed state materials, DOE's weatherization regulations, and the LIHEAP Clearinghouse summary on non-heating Electric Weatherization Programs. 


\title{
A WEATHERIZATION MANUAL FOR LIHEAP POLICY MAKERS AND PROGRAM ADMINISTRATORS
}

\author{
Marjorie J. Witherspoon* \\ Ron Marabate* \\ Melissa Weinhaus* \\ Joel F. Eisenberg** \\ September, 1993 \\ Report prepared by \\ **The Economic Opportunity Research Institute \\ and \\ *The National Association for State Community Services Programs \\ Under Subcontract 86X-SK904V \\ for \\ U.S. Department of Health and Human Services \\ Division of Energy Assistance Administration for Children and Families \\ and \\ Office of Energy Efficiency and Renewable Energy \\ U.S. Department of Energy \\ Oak Ridge National Laboratory \\ Managed by \\ Martin Marietta Energy Systems. Inc. \\ Under Contract No. DE-AC05-85OR21400 \\ for the \\ U.S. Department of Energy
}




\section{INTRODUCTION}

This manual is designed to provide Low-Income Home Energy Assistance Program (LIHEAP) directors with information about weatherization and innovative ways they can utilize LIHEAP funds for weatherization activities. It contains a description of innovative weatherization programs which demonstrate creative uses of LIHEAP funds in weatherization activities. In many of the innovative examples, state and local administrators are coordinating their LIHEAP funds with the U.S. Department of Energy (DOE) Low-Income Weatherization Assistance Program's funding and with a variety of other federal, state and utility company resources. The innovative programs demonstrate how LIHEAP funds can be used in client education, targeting high energy users, staff training, assessment and audits for weatherization services. The reader will find in the appendices lists of contact persons and further descriptions of the programs highlighted. Although designed with LIHEAP directors in mind, the practices and programs highlighted in this malual are of practical use to any state, local or utility weatherization program administrator. The glossary at the end of the descriptive chapters will assist readers with the terminology used throughout the manual.

This manual and the many resource entities cited in its appendices provide ready access to a wealth of state-of-the-art information which could lead to a more cost-effective expenditure of LIHEAP weatherization dollars.

\section{FEDERAL LOW-INCOME RESIDENTIAL ENERGY PROGRAMS}

There are two federal programs which address the major energy needs of low-income households: The Department of Health and Human Services' LIHEAP and the DOE's Low-Income Weatherization Assistance Program.

\section{Low-Income Home Eneray Assistance Program}

LIHEAP is one of seven block grant programs originally authorized by the Omnibus Budget Reconciliation Act (OBRA) of 1981. The purpose of LIHEAP is to assist eligible households to meet the costs of heating and cooling their residences. As authorized by the LIHEAP statute, federal LIHEAP funds may be used by grantees for the following types of assistance:

- home heating and cooling assistance;

- energy crisis interventions (with a reasonable amount reserved, based on prior years' data, until March 15 of each program year);

- low-cost weatherization or other energy-related home repair (not to exceed $15 \%$ of funds allotted to or available to a grantee except that a grantee may request a waiver that increases the amount of LIHEAP funds a grantee may use for weatherization from $15 \%$ up to $25 \%$ ). 
According to the U.S. Department of Health and Human Services, 45 states allocated an estimated $\$ 135$ million in FY 1992 for low-cost weatherization activities or other energy related home repair. This is approximately $41 \%$ of all LIHEAP and DCE Weatherization funds that were used for weatherization activities during FY 1992. A majority of these LIHEAP funds were spent under DOE Weatherization rules and regulations.

At the states' discretion, LIHEAP funds may be spent on weatherization. In general these funds may be spent under the same rules and requirements as the DOE Weatherization Program. However, there are some differences that must be adhered to: for example, under DOE Weatherization rules, an entire building may be weatherized if occupants of two thirds of the units are eligible for DOE Weatherization assistance (one half for two or four unit buildings). LIHEAP funds may only be used to weatherize units of those households that are eligible for LIHEAP. In such cases, some grantees may use LIHEAP funds to weatherize the units of those who are eligible for LIHEAP and use DOE Weatherization funds for the remaining units. Another example of a difference in the rules governing LIHEAP and the DOE Weatherization Program is the fact that LIHEAP recipients must be offered an opportunity for a fair hearing if their application is denied or not acted upon with reasonable promptness. DOE Weatherization does not require such a fair hearing. In June, 1993, HHS issued LIHEAP Information Memorandum, LIHEAP-IM-93-20, pointing out the necessity for grantees to adhere to these differences in spending LIHEAP funds for weatherization. Whenever the statement is made throughout the remainder of this manual that LIHEAP weatherization funds are spent under DOE Weatherization rules, the reader should keep in mind that DOE Weatherization rules may be used only when they do not conflict with LIHEAP requirements and that LIHEAP requirements must be used where they differ from DOE Weatherization requirements.

\section{The DOE Low-Income Weatherization Program}

The DOE Weatherization Program is the nation's largest low-income residential energy conservation program. It was created by the Energy Conservation and Production Act of 1976 (PL 94-385). The Federal Energy Administration (FEA) became the federal lead agency in administering "weatherization" program grants to the states in 1976. The U.S. Department of Energy took over administration of the Weatherization Assistance Program in 1979. The DOE Weatherization Program, recently reauthorized in the State Energy Efficiency Programs Improvement Act of 1990, is now guided by rules published in the Federal Register (Vol. 58, No. 41, Thursday, March 4, 1993, page 12514).

DOE's funding efforts have been substantially supplemented since the mid-1980's by the states' receipt of Petroleum Violation Escrow (PVE) funds. These funds came from federal cost overcharge litigation settlements with the major petroleum companies and have been used, in part, by the states to fund weatherization activities. Like the LIHEAP weatherization funds, the expenditure of 
PVE funds for weatherization has usually been guided by the DOE Weatherization Program rules and regulations. Added to the direct DOE Weatherization Program and LIHEAP program efforts are the diverse energy conservation resources of local utility companies, state and locally-funded conservation/housing programs, other federal block grants, and private foundations.

\section{DOE'S NATIONAL EVALUATION}

In 1990, DOE embarked on a three-year evaluation of its Low-Income Weatherization Assistance Program. DOE's Weatherization Assistance Program Division contracted with Oak Ridge National Laboratory (ORNL) to help design and conduct the evaluation (Beschen and Brown, 1991). This major weatherization evaluation effort is composed of the five separate studies that follow:

1. A description of the DOE Weatherization Program network's characteristics and innovations. It thoroughly surveyed DOE Weatherization Program grantees and subgrantees to detail their internal and extemal relationships, their methods of operations and staffing patterns, plus many other areas of DOE Weatherization Program involvement. This report has been completed and released as "Characteristics of the Weatherization Assistance Program Network," (Mihlmester, et al., 1992).

2. A profile of eligible clients and an assessment of non federal resources applied to weatherization. This study surveyed DOE Weatherization Program grantees, subgrantees, and 124 utility companies to compile valuable data on dollars from various funding sources, homes weatherized, and a characterization of the total eligible population. This product has been completed and released as "Scope of the Weatherization Assistance Program: The Weatherized Population and the Resource Base," (Power, et al., 1992).

3. A fuel-oil study of about 250 single-family homes weatherized in 1991 and 1992 in nine northeast states. Due to be published in late 1993.

4. A high-density multifamily study of the effectiveness of weatherization work performed in 1989 on multifamily buildings with 5 or more units. Due to be published in late 1993.

5. A single-family study, including about 20,000 owner and renter-occupied electric and gas-heated homes weatherized in 1989 by over 400 subgrantees in every region of the country. This is the largest component of the national evaluation, as well as the component seeking to assess the impact of the most varied delivery and installation options. The findings of this study were reported in "National Impacts of the Weatherization Assistance Program in Single-Family Homes." (Brown, et al., 1993).

The "Scope" study's characterization of the weatherization assistance resource base provided a starting point for identifying innovative uses of LIHEAP funds for weatherization services to low income households. Subsequently, the HHS Division of Energy Assistance in the Administration for Children and Families, the federal office with oversight of the LIHEAP program, provided funding to DOE's evaluation project to expand upon the "Scope" study by identifying innovative programs which used LIHEAP funds to extend the reach of weatherization services. The final product is this 
manual which is intended to help LIHEAP managers to identify, plan, and implement innovative LIHEAP-funded activities in conjunction with DOE's Weatherization program. ORNL contracted with the Economic Opportunity Research Institute (EORI) and the National Association for State Community Services Programs (NASCSP) to produce this manual.

\section{THE SCOPE OF WEATHERIZATION}

Weatherization is a generic term, which covers a host of energy conservation activities. On one end of the spectrum, programs can follow a low cost/no cost approach. This may encompass as little as providing a low-flow showerhead, some rope caulk, and a couple of electrical outlet insulators. On the other end of the spectrum, there are some comprehensive, multi-source funded programs that will air-seal a home's interior, install R-33 of attic insulation, add a complete highdensity insulation package to the home's sidewalls, perform detailed diagnostic and repair services to the heating system, plus perform needed structural rehabilitation work, such as roof replacement. In the middle of the spectrum are programs which clean and tune furnaces, provide attic and wall insulation, perform modest repairs, wrap hot-water heaters, and replace windows and doors. All of these programs are considered "weatherization" programs by various constituencies.

The DOE Weatherization Program is a mid-range program offering extensive energy conservation services to low-income persons. As will be seen in the innovative programs outlined below, the use of LIHEAP and other funds can substantially broaden the scope of the DOE Weatherization Program services to achieve a more comprehensive treatment.

If there is such a variety of weatherization activities, then the logical question is what activity, or combination of activities, should be performed? There may not be a perfect answer to that question. Federal regulations guide the use of DOE Weatherization Program funds. Insofar as states have decided to use LIHEAP and PVE funds for weatherization, they have spent the majority of them under DOE Weatherization Program regulations. However, some states have taken advantage of the fact that LIHEAP regulations are less restrictive than DOE's regulations. In these instances, LIHEAP funds are generally used to address needs that cannot fully be addressed under the DOE rules, particularly heating systems repairs/replacement and rehabilitation needs.

When the energy conservation funds of utility companies, other federal housing funds, and private foundations' monies are added to the overall program equation, a variety of services and dollar-limit options are introduced.

The latest research data generally supports the provision of a combination of structural and

mechanical system weatherization measures, if funding allows for such a level of services. These researchers indicate that when structural air-sealing is combined with attic and high-density sidewall insulation, there is significant energy savings at a very attractive cost benefit level. A total cost for these basic structural retrofits might range from $\$ 600-\$ 1,300$ for an average size home. The 
resulting energy savings could potentially reach 15 to $25 \%$ of a home's total energy use. Likewise, when a low-efficiency, non-repairable, heating system is replaced, the energy conservation impact is quite impressive, often as high as $25 \%$ of the home's prior fuel usage. However, when dealing with total heating system repiacement, the cost factor can range anywhere from $\$ 1,000-\$ 2,500$ or more for an average size home (the final cost being dependent upon prevailing costs not only for the furnace, but also for any associated costs that have to be included, such as ducting, electrical, asbestos removal, etc.). The energy reduction impact of combining any two or more retrofit measures is generally not cumulative.

\section{IDENTIFICATION OF INNOVATIVE PROGRAMS}

The manual identifies innovative programs which extend the coverage of weatherization services provided through the DOE Weatherization Program and go beyond the conventions of that program through the use of LIHEAP funds. In addition, it identifies model approaches for LIHEAPDOE Weatherization Program cooperation and integration, model client education practices, and model quality control and inspection practices.

An initial pool of potential innovative organizations was identified using the following process:

1. A review was made of the extensive survey information gathered from the "Characteristics of the Weatherization Assistance Program Network" study by Mihlmester et al. In reviewing state DOE Weatherization Program grantee responses for the 1989 Program Year, focus was placed on identifying states that noted that they performed or promoted quality workmanship, innovative energy education, innovative management practices, and new programs development/cooperative efforts. In reviewing the responses of subgrantees, focus was placed on identifying those subgrantees whose performance was above the mean and median for: the number of weatherized single-family and multifamily structures; referrals to other public services; providing other onsite services; operating energy programs aside from the DOE Weatherization Program, and reporting the use of specific diagnostic/screening techniques and measures.

2. A review was made of states which spent some of their LIHEAP dollars on weatherization. A list of candidate states also was compiled from a review of LIHEAP Profiles of grantee activities.

3. Potential innovative programs were also solicited from DOE, HHS, national associations with interests in energy conservation, plus a number of state administrators from NASCSP's own membership rolls.

4. An initial pool of 23 potential innovative programs were selected. Those 23 programs were asked to complete a questionnaire and to submit additional program information. They were contacted by telephone for further clarification of the information submitted. As a result of this process, the final eight innovative programs were selected. 
This comprehensive identification and selection process resulted in innovative programs which offer a valuable scope of varying program designs and operations. The innovative designations are not meant to imply that other state or local LIHEAP entities are not carrying out productive or innovative energy conservation activities. Although NASCSP used information gathered from a wide variety of sources and a complex screening process, there may still be innovative programs that were not identified. Therefore, the innovative programs selected art not meant to represent the universe of programming options, but are presented to provide the reader with some of the most innovative options for utilizing LIHEAP dollars for the weatherization of lowincome households.

\section{PATTERNS FOR INNOVATION}

Several common features were identified in telephone interviews with state and local administrators that characterize innovative programs and their management. These features address how state managers conduct their own business as well as how they relate to the subgrantees responsible for local program implementation.

\section{Making Change Routine}

One common characteristic is that organizations that are now on the cutting edge of energy conservation technology are ones that have routinely reexamined the way they do business. There is continual and aggressive action taken to "do better." For example, the systematic evaluation of existing procedures and periodic reevaluation of program performance have enabled California and New York to improve the quality of their audit instruments and installation protocols. Experimental program designs and pilots have produced replicable models for improved application of technologies like blower doors in Minnesota and better client education programs in Washington.

In these cases, measurement of performance with a critical eye, testing of new methods and program designs, and incorporation of successful models and ideas into system-wide procedures are part of the program routine. These are states where weatherization is a dynamic rather than a static system with regular procedures to encourage productive change.

\section{Leadership}

A second common characteristic of innovative programs is that their directors are not only managers but also leaders. The kinds of programs that nurture improvement and change are those in which directors are not satisfied with the status quo. They are oriented to the goal of improved client service in an environment where resources are scarce but opportunities to develop new resources can be identified and exploited. They pursue funds from multiple funding sources and develop 
coordinated approaches to solve their unique client needs. They initiate pilot projects, and then based upon the results of the pilots, programs are expanded throughout the state.

Washington's philosophy, from the governor on down, explicitly emphasizes leveraging and resource integration as a management objective. The local agency network has been encouraged to develop partnerships with local electric utilities. New York regularly initiates joint ventures with the state Energy Research and Development Authority and other outside agencies to identify and pilot new concepts for funding and program improvement. This helped lead to the creation of the weatherization investment procedure known as the Targeted Investment Protocol System (TIPS).

In short, the leadership of these states and agencies create an environment from the top down that encourages better program performance and innovation by those they supervise. They cultivate organizations that consist of people who are motivated and committed to excellent performance.

\section{Local Initiative}

A third key characteristic is the state's willingness to empower local subgrantee agencies with the discretion and authority to make critical decisions. California, Massachusetts, Minnesota, and New York are particularly noteworthy in this regard. These are states that have recognized that the key decision-making level for effective weatherization may be at the weatherization job site itself. They have worked to create agency contracts, audit instruments, and installation protocols that will facilitate good choices and techniques by local weatherizers.

The local administrators and auditors, in tum, make the key calls about what funds to use and how to mix and match them. The local agencies are relied upon to have a keen understanding of the local conditions and, particularly, the network of local contractors that will be performing heating system work. The flexibility provided by LIHEAP funding and rules has played a key role in enabling this kind of effective local decision-making to occur.

\section{Coordination}

A fourth common characteristic is the ability of innovators to view the objectives of providing low-income energy assistance, energy conservation, and housing rehabilitation as part of a related package of client services. The individual program parts, when properly coordinated, yield a much greater and more beneficial whole to the client and the program.

In Colorado, for example, the transfer of LIHEAP referral lists to weatherizers helps them to prioritize high-consumption households because LIHEAP includes household energy consumption data from utilities in its lists. In Illinois, the Housing Development Agency sets aside $\$ 2$ million of HOME funds to be accessed by local weatherization program operators for needed structural repairs enabling the weatherization of housing units that would otherwise have to be rejected by the weatherization program. 
In some cases coordination involves sharing information, as in the Colorado example above. In others, the integration or leveraging of funds from a variety of sources are brought to bear at a single point, the low-income home, to produce a safer, more cost-efficient dwelling. In all cases the program managers have reached out beyond their own direct lines of responsibility to identify "winwin" situations with managers in related fields.

In summary, weatherization is most effective and efficient when all available resources are coordinated in a dynamic system that is flexible, innovative, performance based, and responsive to available opportunities. This takes leadership. State LIHEAP and DOE Weatherization Program administrators can work with each other, local utility companies, and local DOE Weatherization Program operators, private contractors and with critical equipment/material suppliers, to implement a very effective and efficient statewide weatherization programming effort imbued with these characteristics.

\section{NEW OPPORTUNITIES}

The State Energy Efficiency Programs Improvement Act of 1990 enabled many changes to DOE's Weatherization Program. The final rules implementing these changes, however, were not published until March, 1993. As a result, our survey of innovative programs preceded any programmatic transformations resulting from the Act.

Many of the innovative programs used LIHEAP funds for weatherization activities that were not allowed under the previous DOE Weatherization Program's rules, but which are now permitted. For example, California used LIHEAP funds for ceiling fans. DOE Weatherization Program funds can now be used for the purchase of ceiling fans. A number of states utilize LIHEAP funds for furnace replacement and repair. These have traditionally been allowed under the DOE program; however, states chose not to use DOE funds for this purpose because of the dollar limit on the expenditures in each dwelling. States may now develop a separate average per dwelling expenditure limit to cover capital intensive work on heating or cooling systems.

Consequently there may be some states that no longer will use LIHEAP funds for these purposes. It remains to be seen how the new regulations will modify the relationship between DOE and LIHEAP weatherization resources and the specific programs and procedures highlighted in this manual may become somewhat less relevant as these relationships are clarified.

It is therefore important to emphasize that the manual also provides insight into the kind of generic systems and procedures that can foster productive innovation and change at the state and local level. It is hoped that these, as much as the specific programs highlighted, will prove to be useful models for LIHEAP Directors. 


\section{CALIFORNIA}

Highlighted Activities: Installation of Ceiling Fans; Staff Training; Quality Control; Leveraging; Assessment and Program Auditing

\subsection{ADMINISTRATIVE STRUCTURE}

The Department of Economic Opportunity is the state department responsible for the administration of LIHEAP, the DOE Weatherization Program and PVE funds. Contracts with local agencies are handled by the same state staff and administered in the same state unit. This unit is also responsible for the administration of the Community Services Block Grant.

The State of Califomia uses LIHEAP, DOE Weatherization Program and PVE funds in a variety of integrated and effective ways. Local contractors receive two contracts from the state. One provides guidance on the use of DOE funds and the other on the use of LIHEAP funds. In some instances, local contractors combine LIHEAP and DOE Weatherization Program funds to maximize the number of retrofit measures provided in individual dwellings and to increase the dwelling's overall energy efficiency.

The state sets guidelines for the overall use of LIHEAP, DOE Weatherization Program and PVE funds. When local agencies leverage other funds (i.e. from utility programs) the guidelines are locally determined.

\subsection{HIGHLIGHTED ACTIVITIES}

The state's programming rules allow for LIHEAP dollars to be used to install some retrofit measures that were not allowed under DOE's previous regulations, such as ceiling fans.

PVE funds were used for staff training, particularly training on the state's Weatherization Installation Standards manual, the use of blower doors, and carbon monoxide analyzers. Recognizing the diagnostic capabilities of blower doors to locate and quantify air leakage sites within a structure, plus the benefits related to assessing occupant health and safety risk factors, California requires its subgrantees to use blower doors on at least $10 \%$ of all single-family dwellings and on $100 \%$ of all mobile homes to be weatherized.

The California standards also call for a combustion appliance safety check on all units scheduled for weatherization services on which blower door testing is performed. Quality control and inspection practices are strengthened by the state's use of independent inspectors, who are paid for by PVE funds.

Many of the state's weatherization contractors have secured added program funds through agreements with private and municipal utility companies. Sierra Pacific Power Company, 
CP National, Pacific Gas and Electric Company, Sacramento Municipal Utility District, Southem California Gas Company, Southern California Edison Company, San Diego Gas and Electric Company, Pacific Power and Light Company and Southwest Gas Company all contract with many of the state's weatherization subgrantees. Utility resources are coordinated and integrated with the LIHEAP weatherization program through the single intake process the agencies provide for their weatherization services. This intake allows the agencies to determine which program best meets the need of the individual client. The incorporation of the utility funds allows for the weatherization of more LIHEAP eligible households. Also, as with the Southern California Gas Company program, funds are provided for the repair or replacement of appliances during the time that the dwelling is being assessed for LIHEAP w'eatherization services.

Both the Southem California Gas Company and the Pacific Gas and Electric Company provide basic, advanced and mobile home weatherization training to staff of state subgrantees.

Many of these same contractors receive discounts on the purchase of weatherization materials. Savings from discounts allow for additional LIHEAP eligible homes to be served. Most local agencies have also negoualed with licensed mechanical contractors to waive service call fees for repair and replacement of heasing systems, plus reduced labor charges for the installation of other weatherization measures Some contractors have been able to waive freight charges associated with the delivery of purchased materials. These are examples of ways that a local program can save LIHEAP and DOE Heathenzation Program funds.

As with any sound weatherization program, the State of California was interested in documenting the impact of its weatherization programming efforts. Therefore, in 1985 the state contracted with an outsuse consultant group to perform a formal assessment of its statewide program. The 1986 final repon noced an average 20\% energy savings for the measures that were installed. Not only do formal evaluatıons provide documentable evidence of past actions, but a good evaluation also provides an organization with valuable data on ways to improve the effectiveness and efficiency of a program. Based upon the 1986 final report, California noted that certain retrofit measures seemed to offer more "bang for the buck" than others.

Until that time, Califomia had used DOE's Project Retro-Tech home auditing instrument to determine the retrofit measures that should be installed in a dwelling. However, with the data from their research study, the state developed an entirely new "measures installation" system. The new system delineates a list of mandatory measures and a list of optional measures. The optional measures can only be installed once the mandatory measures have been accounted for and if there are sufficient funds remaining to complete the added optional measures. This system is updated on an annual basis. California is currently reviewing its measures installation system, and will be determining if further revisions are needed to achieve a higher benefit-cost ratio for the funds expended. 


\section{COLORADO}

Highlighted Activities: Client Referral; Targeting High Energy Users; and Crisis Intervention

\subsection{ADMINISTRATIVE STRUCTURE AND CLIENT REFERRAL}

The LIHEAP fuel assistance funds are administered by 61 local social services offices, with client applications channeled into the state Department of Social Services office. With this large data base of LIHEAP eligible clients, the state initiated a process to provide local weatherization program operators with valuable referral data sheets. That process starts with the Department of Social Services developing the referral list by county and sending the lists to the state Division of Housing, which is the state weatherization program grantee agency.

The Division of Housing compiles the county lists by service areas and then forwards the referral lists to the 19 local weatherization subgrantee agencies. These lists have become the primary outreach tool, with $65 \%$ to $80 \%$ of the weatherization clients served being LIHEAP fuel assistance clients. The lists also help program operators prioritize activities. Although LIHEAP and DOE Weatherization Program funds are administered under the same DOE Weatherization Program rules and technical standards, Colorado provides separate contracts for each funding source to its local agencies, and does not allow them to expend LIHEAP and DOE Weatherization Program funds on the same unit.

\subsection{HIGHLIGHTED ACTIVITIES}

\subsubsection{Targeting}

Colorado is a proponent of the theory that homes consuming the most energy are the homes where the most energy savings can be achieved through weatherization services. One of the primary tools used by local agencies to target high energy users is the data received from the LIHEAP lists described above. The LIHEAP lists provide consumption data and type of fuel used. This information is acquired through fuel bills supplied by the client or through information provided by the utilities. This data tells the local agencies how much their clients have spent in the last three winter months on heating fuel, as well as the type of fuel used.

The local agencies are required by the state to serve the elderly, the handicapped and high energy users first. It is the state's strong recommendation that the highest energy users should head the list. The state office is currently working on new guidelines that will stress giving high energy users and homes with heating emergencies the first priority for services.

Just as the referral lists between the LIHEAP agencies and the weatherization operators are one source of coordinated effort, the coordination can flow in the other direction. The state Division of Housing 
annually provides updated weatherization program training to social services' staff. This training allows the fuel assistance staff to be more knowledgeable about the weatherization program and allows them to provide client referrals, as appropriate. Likewise, many weatherization clients are frequently referred to the social services office for fuel assistance.

\subsubsection{Crisis Intervention}

The Crisis Intervention Program (CIP) component of LIHEAP is also an ongoing link between fuel assistance offices and local weatherization agencies. When weatherization agencies encounter heating emergencies (usually heating system repairs or replacements needed), the CIP funds often serve as an additional resource when weatherization funds hit their spending limits.

In one local situation, the county social services office has actually turned over part of the management of the CIP funds to the local weatherization agency. The Energy Resource Center (ERC), which is a local weatherization program subgrantee, now administers the local CIP activities. The ERC, the second largest agency in the Colorado weatherization system, is based in Colorado Springs and serves a large two-county area. Since county funding levels, LIHEAP funding levels, and local social services office staffing were down, the social services office decided to turn over part of the CIP administrative process to ERC. The ERC performs CIP intake tasks, and then immediately faxes the client intake data to the social services office for approval. The social services office will review the client background data and the client's needs, and fax back an approval to ERC.

The ERC has five licensed heating contractors on its staff, which makes it somewhat of a unique local agency, giving it tremendous capabilities in the mechanical systems service area. If confronted with a "no-heat" situation, a "red-tag" due to code problems, or a gas leak situation that is an immediate health and safety problem, ERC can quickly respond with one of its licensed contractors. If the mechanical system can not be repaired at the time of the initial visit, i.e. parts must be ordered or the furnace must be replaced, ERC will leave agency-owned electric space heaters with the client. As soon as the parts or replacement fumace are available, the mechanical system is repaired and the space heaters are removed from the client's home for use somewhere else.

In response to such situations, the agency can average anywhere from $\$ 30-\$ 500$ to resolve the particular heating system problem. Not only can this process be handled in a very expedited fashion, but these clients are also immediately placed in the pool of homes for full weatherization services. 


\section{ILLINOIS}

Highlighted Activities: Furnace Replacement, Retrofit and Repair; Coordination with HOME; Staff Training and Certification; Whole House Energy Audit

\subsection{ADMINISTRATIVE STRUCTURE}

The Division of Economic Opportunity in the Department of Commerce and Community Affairs is responsible for the administration of the DOE Weatherization Program, LIHEAP and the Community Services Block Grant. The funds from LIHEAP and DOE Weatherization Program which are used for weatherization activities are administered through separate contracts with the subgrantees.

\subsection{HIGHLIGHTED ACTIVITIES}

\subsubsection{Furnace Work}

Illinois used its LIHEAP dollars to replace, repair and retrofit inoperable or unsafe heating systems. LIHEAP funds were used to fund the furnace program because of the low per home allowable dollar levels under the DOE program. In this way, LIHEAP funds were used to enhance the level of weatherization benefits which could be provided to eligible households. Households therefore received not only the traditional weatherization services of insulation and infiltration reduction, but also services on their heating systems.

Within the weatherization program, the state used the LIHEAP dollars to install fumaces that can achieve efficiencies of $78 \%-82 \%$. However, under a project involving three utilities, People's Gas, Northern Illinois Gas, and Iowa/Illinois Gas, the state was able to install $90 \%$ efficiency furnaces in over 200 homes. To cover the increased costs associated with these high efficiency heating units, the utility companies contributed $\$ 500$ for each unit. This contribution also can be used by the state to pay for other needed work, such as the purchase and installation of a chimney flue liner. This utility project was negotiated at the state level with the utilities and was not mandated by the Illinois Public Utility Commission. Although this project is not a statewide one, state administrators are hopeful that this program will be expanded.

\subsubsection{Coordination with HOME}

Another use of LIHEAP funds is in coordination with U.S. Department of Housing and Urban Development (HUD) HOME funds. By combining LIHEAP and HUD funds, the state is able to ensure more safe and affordable low-income housing. The state weatherization grantee agency, the Department of Commerce and Community Affairs, negotiated with the Illinois Housing 
Development Agency to set aside $\$ 2$ million of their HOME funds to be accessed by local weatherization program operators for use in the homes they weatherize. The HOME funds will provide needed dollars for structural repairs in homes that might not have been weatherized due to their structural deficiencies. For more information on this project contact the state official listed in Appendix A.

\subsubsection{Staff Training and Certification}

Illinois implemented a staff training and certification program in 1988. LIHEAP dollars play an important part in this vital quality control effort. The state has always felt that there were at least two important components of the weatherization process. One is the field audit of the dwelling, which determines the existing condition of the dwelling and offers possible retrofit solutions. The other component was the final inspection of the dwelling after the work was performed, since this step confirmed that all the appropriate work was actually installed according to specifications. As the state procedures declare, the objective of the certification program is to "provide a level of weatherization service that is uniform throughout the state...(and) the level of knowledge expected of...coordinators, assessors, and final inspectors should be consistent." To accomplish this, the state set up a program, through Lincoln Land Community College, where assessors and final inspectors were initially required to successfully complete four courses: Building Types \& Assessment Fundamentals, Basic eat Transfer/Whole Houx Energy Audit Assessments, Heating Systems, and an Audit Lab course. Within the last year, the Audil Lab course was dropped as a mandatory course, since most local staff had achieved competency in that area. To assure basic competency, the enrolled staff must take and pass a proficiency isst $t)$ tecome a certified Weatherization Auditor.

Local agency weatherization coordinators must take the same four courses (proficiency exam not required), plus one of two management electives. The electives are Basic Management/Supervisor's Role or Work Automation/Quality Control and Project Management. In addition to the mandatory courses, the state now has three elective courses for any local staff. Those three elective courses are: Indoor Air Quality, Building Diagnostics and Mobile Homes. Enrollment in any of the courses is also available to any other local level staff, such as crew leaders, crew workers, subcontractor staff, and/or field supervisors. New hires to the program, must obtain their corresponding certification within six months of their hiring. The certification program is designed to ensure that competent trained personnel deliver the program in a manner which provides the highest level of service to households.

Aside from the immediate benefit to the worker and the weatherization program, there are two other benefits from the certification program. First, the worker may also earn college credits for this coursework and, second, upon completion the worker automatically receives membership in the Association of Energy Engineers, which is a nationally recognized society. 


\subsubsection{Whole House Energy Audit}

Working with the University of Illinois, the state developed a Whole House Energy Audit (WHEA) system. It is a mainframe operated computer system that determines the cost effectiveness of both building envelope and furnace retrofits. A work order listing of all of the recommended retrofits to be added to a home is then generated. The audit also provides the state with information about the measures installed by the grantee agencies and the funds spent. Use of this audit should increase the cost effectiveness of the local grantee agencies' programs. It also improves the state's monitoring capability by providing information about the grantee agencies' weatherization activities. Large scale automated systems are inherently expensive and without the influx of LIHEAP funds it is doubtful that available DOE dollars would be sufficient to cover the costs of the system. 


\section{MASSACHUSETTS}

Highlighted Activity: Heating System Repair and Replacement Program (HEARTWAP)

\subsection{ADMINISTRATIVE STRUCTURE}

The State of Massachusetts administers three distinct energy assistance programs: LIHEAP, HEARTWAP and the DOE Weatherization Program. HEARTWAP pays for emergency repairs to, and replacement of heating systems for LIHEAP fuel assistance clients. These programs are administered by the Office on Energy Conservation in the Executive Office of Communities and Development. In almost all instances, the providers of services for these programs are the same local agencies. There are, however, a few instances in which a local agency may administer only one of the programs. The three programs use a central certification of eligibility that applies to all three programs. All clients are routed to each of the programs.

HEARTWAP clients are referred to the program through a LIHEAP application question, and a weatherization program referral form. HEARTWAP clients needing weatherization are also referred to the weatherization program. This two-way referral system results in timely coordinated application of LIHEAP and DOE Weatherization Program funds, and results in the greatest heating value for fuel assistance dollars. It also enables the state and its subgrantees to make low-income housing more affordable and safer for their clients.

While most subgrantees operate all components of the state's weatherization and HEARTWAP programs, in those communities where there are separate program operators, the state requires a Memorandum of Understanding/Coordination Plan. It is required that if a home is weatherized and is also found to be in need of HEARTWAP services, that it receives priority for HEARTWAP treatment. The same is true of homes receiving HEARTWAP services first; they are to be prioritized for weatherization services. In both situations, the results of any combustion efficiency testing is to be shared with the other service agency.

\subsection{HIGHLIGHTED ACTIVITY}

The HEARTWAP project was first initiated in late 1985 to address heating system problems that the DOE Weatherization Program grant was unable to address. The FY 92 HEARTWAP received $\$ 4.1$ million of the state's $\$ 61.8$ million LIHEAP grant. These were the only LIHEAP funds designated for weatherization activities in Massachusetts in FY 92.

Under the HEARTWAP rules, fuel assistance eligible clients can receive a clean-out/tune-up, repairs, burner replacements, conservation retrofits (vent dampers, etc.), and primary heating system replacements up to a total annual maximum of $\$ 2,250$. An additional $\$ 1,200$ may be expended for 
the purpose of abating friable asbestos in conjunction with an allowable heating system activity. Heating system repairs are limited to $\$ 600$. Program operators are required to seek a $50 \%$ cost contribution for asbestos abatement when the client is a renter and the property owner is not also income eligible. The client is eligible for service on a yearly basis, which assures that systems are maintained at an efficient level, and enhances the heating value of fuel assistance dollars. The availability of the HEARTWAP funding allows for other weatherization funds to be used more for the extensive building shell needs of the homes served.

A multifamily building of no more than six (6) units in which one or more of the households are HEARTWAP eligible, may be eligible to receive heating system assistance in a sum equal to the maximum amount allowable for a specific heating system activity. Therefore, a common heating system replacement for up to a six-family building cannot exceed $\$ 2,250$.

Multifamily buildings of seven or more units are not eligible for HEARTWAP services.

Due to the highly technical nature of the HEARTWAP project activities, staff separate from the regular DOE Weatherization Program were hired to provide extensive training in the areas of heat loss calculations, asbestos abatement, bumer and system replacement, and code compliance.

Technically competent and state-trained individuals may perform the required combustion efficiency test upon oil and gas heating equipment without possessing the required license. These technicians, however, are prohibited from making any actual adjustments to the heating equipment. The technician fills out a standardized report form citing inspection and testing findings. In any situation where system replacement is being recommended, the local agency must first obtain state approval.

Relative to contractor selection for heating system repair work, either the client's customary equipment service vendor or, when that vendor is not qualified, contractors nired through the competitive bid procurement process may be used to perform the work. A competitive bid procedure must be followed for all replacement work.

The entire HEARTWAP project is guided by a set of maximum cost limits.

All clients receiving HEARTWAP services also receive education about their heating system and the work to be performed.

After all services are performed by a contractor, the local HEARTWAP agency is responsible for performing a post-work combustion efficiency test and for assessing the overall work of the contractor. A one-year warranty for materials and installation must be provided by the contractor in writing for all bumer or heating system replacements. 


\section{MINNESOTA}

Highlighted Activities: Reweatherization; Heating Systems Training; M-200 Audit Project

\subsection{ADMINISTRATIVE STRUCTURE}

In FY 92 Minnesota had $\$ 15.27$ million for weatherization programming: \$2.6 million from LIHEAP; $\$ 9.31$ million from DOE; $\$ 2.54$ million from PVE funds and $\$ .82$ million from the Minnesota Legislative Energy and Conservation account which comes from fees collected on liquid petroleum (LP) gas sales and fees on oil/petroleum sales. All funds are administered through the Department of Jobs and Training's Community Based Services Division. The state provides two contracts to its local agencies. One contract is for DOE and PVE funds and follows the DOE rules and regulations. The other contract contains LIHEAP and the legislated energy funds. The state has developed the rules by which the LIHEAP and legislated funds can be used. The state encourages local agencies to exercise their own discretion within the guidelines provided as to which funds are the most appropriate to use in the various homes they weatherize. Funds from all sources can be used in any house.

The state uses the LIHEAP funds to supplement the regular DOE Weatherization Program, but also to build upon the activities of the DOE Program and allow local subgrantees to provide cornprehensive conservation-related repair and reweatherization services, vital client education activities, and cost-effective mechanical system repairs and replacement. The LP and oil funds are designated and matched with mechanical systems activities where the primary fuel source is LP or oil. In developing this coordinated funding and services approach, the state has set up program guidelines to allow subgrantee agencies greater flexibility to perform more complete energy savings measures. A local agency may expend up to $\$ 3,000$ of their grant funds on a dwelling unit for any combination of allowable conservation strategies. These allowable strategies are detailed in a comprehensive state manual.

\subsection{HIGHLIGHTED ACTIVITIES}

\subsubsection{Reweatherlzation}

One of the interesting uses of LIHEAP funds in Minnesuta is to allow local agencies to go back to homes previously weatherized and provide added services. DOE Weatherization Program rules allow for very limited reweatherization work. Under the Minnesota system, the agency can use LIHEAP funds to return to a previously weatherized home if one or more weatherization priority measure was not installed due to a lack of funds. The household must still be program eligible. Repair work can be completed along with previously missed measures. Reweatherization work cannot 
exceed $\$ 1,000$. As with DOE Weatherization Program rules, these units cannot be counted by the agency as a newly weatherized unit. They are counted in a reweatherized category.

\subsubsection{Heating Systems Training}

As noted previously, the LIHEAP funds are also used to deal with inoperable or inefficient mechanical systems found in the homes of eligible clients. As a result of the extensive work funded by LIHEAP in the area of mechanical inspection and retrofit activities, the state opened an expansive and well-equipped furnace technician training center in 1990 funded with DOE training and technical assistance dollars. The center, just outside St. Paul, has one or more of each type of heating system--all operational and ready for hands-on instruction and demonstration. Another interesting training component is the "Energy Busters" interactive computer program that allows trainees to simulate a mechanical system audit. The state not only trains its local agency staff at the training center, but also runs classes for the mechanical contractors that perform work for the local agencies. In fact, those contractors must receive training from the state to be eligible to perform work for the state program.

All mechanical wunt is to be competitively bid, unless state-approved standard prices have been approved. The contractors must be licensed and trained by the state, and possess statedetermined minimum incurance coverage levels. The contractors must also agree to a specific Contractor-Homeouner Harranty agreement.

\subsubsection{M-200 Audil Prolect}

Minnesols $w_{2}$ s recently involved in a landmark research project on cost effective energy retrofit procedures. The M 200 Enhanced Low-Income Weatherization Demonstration Project," was initiated in 1988 and uas conducted by the Underground Space Center of the University of Minnesota with the involvement of several nationally recognized resource people.

The M-200 Project used nine of Minnesota's local weatherization agencies, including Ramsey Action Agency, to weathenze 200 homes using a newly-designed "protocol." That enhanced system had these features, as cited by the project's final February 1990 report:

a. The audit and crew work procedures were revised to assist in diagnosing the most cost-effective retrofits for each individual home.

b. The decision-making process was decentralized right down to the crew level.

c. The blower door was used for pre-weatherization tests, during air sealing, and in post-weatherization inspections. There was also a protocol used to stop air sealing when no longer cost effective.

d. The availability and use of infrared cameras for audits, air sealing, and postweatherization inspections were increased. 
e. Sidewall insulation procedures were modified in order to reduce conductive heat losses as well as seal important air leakage sites that were difficult and time-consuming to fix by conventional air sealing methods.

f. An occupant education protocol was established to increase weatherization energy savings by involving the client in all facets of home weatherization, and final inspection.

g. Greater attention was paid to furnace performance, proper distribution, and cost-effective mechanical system retrofit.

h. Most importantly, the procedures were modified to assure a safe and healthy environment for the occupants as well as durability for the house structure. A minimum ventilation standard was set for air sealing work. A limit was set for air sealing consistent with American Society of Heating, Refrigerating and Air Conditioning Engineers (ASHRAE) ventilation standards. Special attention was given to correct conditions leading to moisture and ice dams, and to eliminate sources of possible air pollutants from the ground and from combustion sources.

The M-200 Project findings, based upon a final pool of 128 homes weatherized, showed an average $36 \%$ reduction in air leakiness, for a total per home average labor and materials cost of $\$ 1,306$ ( $\$ 1,571$ when overhead and administration were included). Using the Princeton Scorekeeping Method (PRISM) energy savings calculation system, the M-200 researchers determined an overall average energy savings level of $17.7 \%$. When compared to a 1986 study performed in Minnesota, the M-200 results "provided ...payback periods nearly half of those measured in 1986 (and)...the net adjusted percent energy savings...was $160 \%$ greater..." Therefore, the researchers went on to conclude that the M-200 Project showed that:

...by decentralizing the decision-making process, stressing cost-effective weatherization work, and actively enlisting the cooperation of the client, production-based low-income weatherization can achieve large energy savings, low payback period and greater client satisfaction.

Today, the state of Minnesota and its local agencies have incorporated many of the M-200 protocols into the standard statewide home weatherization program. 


\section{NEW YORK}

\section{Highlighted Activities: Heating System Services/Coordination between LIHEAP and DOE Weatherization Program; a New Audit System -- TIPS; Staff Training and Results of State Study}

\subsection{ADMINISTRATIVE STRUCTURE}

There are ninety-one DOE Weatherization Program subgrantees covering all sixty-two counties of the state. To assure the coordination and effectiveness of the overall weatherization program effort, the state's Department of State has developed a comprehensive program policies and procedures manual. Utilizing this document, all parties involved in the state's weatherization program can easily access the latest program directives. In reviewing the New York weatherization policies and procedures, the commitment to quality is highlighted by the fact that all dwelling units weatherized must be inspected by local agency personnel after the work is completed. The state office supports this effort, by having its own field representatives visit local agencies and reviewing a minimum of $20 \%$ of all completions. New York State's Department of State also administers the Community Services Block Grant; however, the LIHEAP program is administered in the Department of Social Services. In FY 92, the state extended its commitment to the weatherization program by allocating $\$ 17.5$ million of its LIHEAP block grant funds to the state's weatherization program.

\subsection{HIGHLIGHTED ACTIVITIES}

\subsubsection{Heating System Service Coordination}

As early as 1985 the state implemented mandatory testing of all primary heating systems on units audited for weatherization. Tuning and cleaning of heating systems with efficiencies below $75 \%$ are now the first priority for work, and are performed by qualified heating contractors. Additional furnace modifications, up to and including repairs or replacement of the furnace and work on the heating distribution system, are now high priority program activities. In line with the priority for mechanical systems work, the State of New York initiated an Emergency Furnace Replacement Program in New York City. This initiative resulted in increased coordination between DOE Weatherization Program and LIHEAP. This coordinated furnace replacement project provides a necessary link between state and local agencies while combining both DOE Weatherization Program and LIHEAP funds. Part of the success of this effort was that it reduced administrative procedures, eliminated duplicative activities and sped up the approval process for installing furnaces under emergency conditions where the system was inoperable.

Under the project, clients had to reside in a 1- to 4-unit building, and were responsible for making the initial request for help to the Community Development Agency (CDA) in New York City. 
CDA initiated the communication, and contacted one of the two NYC weatherization subgrantees. Bids for the work were obtained from private contractors working under the direction of the weatherization agencies and were submitted to CDA, who in tum contacted the NYS Department of Social Services for the required authorization to proceed with the work. The work was done under the supervision of the local weatherization agency.

After this emergency service was provided and the heat was restored, the weatherization agency returned to the structure, conducted a full energy audit of the building and arranged for weatherization services to be provided. After this initial success, the project was also expanded to include the rest of the state outside of NYC. Local departments of social services work with weatherization subgrantees to make additional LIHEAP funds available for furnace replacements. A second aspect of the overall coordination of activities between the weatherization network and LIHEAP is that local depanments of social services also regularly review their fuel assistance and public assistance cascluads. and refer the households with the highest fuel consumption levels, utility arrearages or other energ! nroblems to the local weatherization agencies. This referral coordination helps to assure that LIHE: AP fuel assistance clients with the greatest potential to save energy receive priority for weatherizalıun services. Also, all of the necessary data regarding household eligibility and living arrangements are entered onto a multi-copy form that was designed by the state and local agencies providing the snice. This form is computer entered and assures a method for tracking the status of each client. Muscholds referred under this program are contacted by letter or by personal visit and are offered pronty service by the local weatherization agencies. The state's DOE Weatherization Program office tracks all referrals on its computer to determine final actions at the local level.

This coordinated referral procedure has now been extended to local departments of aging, who refer their vulnerable elderty fuel assistance clients to the local weatherization agencies. This not only gets the elderly client lined up for needed home weatherization services, but also assists these seniors in securing other vital human services through the weatherization agency's other programs and contacts.

\subsubsection{Targeted Investment Protocol System}

New York program administrators have initiated a statewide system that puts more discretion into the hands of local auditors. This procedure is called the Targeted Investment Protocol System (TIPS). Under the unique TIPS approach, three factors-fuel consumption, weather, and size of the heated dwelling area-are entered into the TIPS computer program. Then an analysis of the information compares the fuel use of the building with other buildings of comparable size and location. This analysis serves as a reliable guide for the dollar investment that will be made in the dwelling. Using this analysis, a building auditor uses a blower door and, where appropriate, an 
infrared camera to conduct an instrumented audit. The blower door is used to depressurize the dwelling so that pathways of air leakage can be detected. The infrared camera detects energy loss through the building envelope. Investment of weatherization dollars is then targeted to where the savings will be greatest.

The state believes that under the TIPS process, the level of work on any specific dwelling can be individualized to that dwelling. This is not the typical home auditing approach. New York's program director adds:

If the dwelling unit requires an expenditure of only $\$ 500$, no more than that will be spent. But, the $\$ 500$ will be spent in such a way that the greatest potential for savings can be achieved. On the other hand, if the dwelling requires an expenditure of $\$ 2,300$, the program will provide a more extensive treatment. Recent studies indicate savings of thirty percent (30\%) in energy expenditures after weatherization using TIPS, compared to eighteen percent (18\%) using the traditional weatherization approach, and a virtual doubling of energy savings per public dollar spent.

TIPS is an innovative program approach, and one that followed comprehensive review of the existing research, creative strategizing, pilot testing, re-evaluation, and then a statewide implementation.

\subsubsection{Staff Training}

DOE Weatherization Program and LIHEAP funds are also used to provide extensive training for all local program staff. The state is concentrating on training in the areas of heating systems, blower doors, infrared scanners, innovative energy auditing, mobile home technology and other areas requiring a high degree of technical knowledge and expertise.

\subsubsection{State Evaluation}

Program quality and effectiveness in New York is also based upon periodic evaluation efforts. A recent effort involved the Department of State and the New York State Energy Research and Development Authority (ERDA). A study was conducted to investigate the feasibility of using blower doors more in the auditing process. The state concluded that "this technology will improve the program and assure verifiable energy savings." As part of the study, four agencies in upstate New York were selected for participation. Using blower doors and other analytical tools to perform the initial energy audit, they determined the scope of work and performed the weatherization. In total, about 100 dwellings were weatherized. Two agencies used their own crews, one used a subcontractor, and the fourth agency utilized a combination approach comprised of an initial air infiltration crew followed up by an insulation subcontractor. The study determined overall energy savings to be 
approximately $22 \%$, and also noted that "...using analytical techniques to show where problems lie and to quantify retrofitting progress results in a net savings of time and money."

This study confirmed what other studies have also suggested, namely that final energy savings for any dwelling seems to be related to at least three factors which should be considered before a decision is made to weatherize, or how to weatherize. Those factors are:
a. The initial energy consumption level of the dwelling, measured relative to Btu used per square foot of home size per the Heating Degree Days factor for the geographic area;
b. The leakiness of the dwelling as calculated by using the blower door; and
c. The site of the dwelling, or its location relative to other buildings, trees, shrubs, etc. that could shield the dwelling.

This research/evaluation effort, plus efforts that preceded it, were the basis for the TIPS procedures cited earlier.

New York state has also moved ahead on a statewide computer system that will provide a comprehensive software package for local agencies, and that will eventually electronically transfer basic program data on production, expenditures and other data elements from the local agencies. 


\section{WASHINGTON}

Highlighted Activities: Coordination and Integration of Multiple Funding Sources, a Consumer Education Pilot Project; and Staff Training

\subsection{ADMINISTRATIVE STRUCTURE}

The Housing Division in the Department of Community Development has responsibility for the administration of the DOE Weatherization Program and the LIHEAP weatherization portion while the Community Assistance Division in the same department has responsibility for the administration of the energy assistance portion of LIHEAP. The state provides separate contracts for each of its weatherization program, i.e. one for LIHEAP funds one for DOE Weatherization Program and one for utility or state funded programs. Each of the contracts has separate rules guiding its funds.

\subsection{HIGHLIGHTED ACTIVITIES}

\subsubsection{Coordination and Integration of Multiple Funding Sources}

State and local subgrantees have been able not only to combine LIHEAP and DOE Weatherization Program funds for basic weatherization conservation services, but there are considerable utility company funds for demand-side management programs, Farmer's Home Administration Housing Preservation grant funds, Washington State Housing Assistance Program funds, Community Development Block Grant Homeowner Repair funds, and Housing and Urban Development Rental Rehabilitation Program funds. The state is appropriating petroleum violation escrow account funds and state funds into a special "Energy Matchmakers Program." The whole state philosophy, from the Governor's Office to the local community action agency, is geared towards leveraging every possible source of funding to allow for providing the most comprehensive package of weatherization and rehabilitation services to eligible low-income clients.

Considerable time and effort has been invested to build a partnership between all public utility districts and the parties of interest. The utility companies of that region: Puget Power, Washington Power, Cascade Gas, Bonneville Power Administration; the various state agencies; and the local subgrantee network have come together to meet a common challenge- the energy conservation needs of the state. One local program manager noted that what had been an adversarial relationship years ago between the community action agency network and the state weatherization program office, had turned around over the last five years into "a very strong partnership." He credits this positive working relationship to a new team spirit, and the willingness of both parties to work cooperatively towards common goals. 
That cooperative partnership has produced an exciting spectrum of services. The director of The Opportunity Council, which is a local weatherization subgrantee agency servicing a large threecounty area in the northem part of the state, says that it took over 15 years of commitment, advocacy, and dedicated service delivery to achieve the comprehensive program status that his agency now enjoys relative to housing and energy conservation services that can be directed to his 11,000 eligible low-income clients. The Opportunity Council, using multiple funding sources in a very creative manner, can send its field auditor to a home and, basically, supply all the services that the home needs to achieve maximum energy savings, as well as address any health or safety factors impacting the home. What the director states is that,

\footnotetext{
"We do not want to revisit the house down the line. We provide energy education, lighting efficiency, retrofits, blower door driven infiltration reduction and ventilation, all insulation necessary, door replacement, thermopane windows, water conservation measures, etc."
}

He adds that LIHEAP funding has been used to leverage other housing rehabilitation funds to "fully retrofit the house for homeowners (and) to alleviate health and safety related conditions at the time of weatherization." The Opportunity Council has $\$ 740,000$ of weatherization program resources for the FY 93 program period, including $\$ 170,000$ of very flexible LIHEAP funding.

At the state level, $\$ 4.1$ million, or $14 \%$, of Washington's $\$ 29.03$ million LIHEAP allotment went for weatherization program services in FY 92. Washington's DOE FY 92 allocation was $\$ 3.86$ million, and the state itself contributed $\$ 4$ million. There was an additional $\$ 1.53$ million of PVE funds available to the program. Added to this funding base is all of the utility company and other leveraged funding that the state's 26 local subgrantees have secured.

The state has historically taken advantage of LIHEAP block grant flexibility. Local programs can spend an average of $\$ 2,300$ per unit using LIHEAP funds compared to the DOE Weatherization Program level of $\$ 1,697$ for FY 1992. Further, the state encourages agencies to combine funding sources to ensure that all cost-effective measures are installed. Going back to The Opportunity Council's local program, the director notes that his program averages about $\$ 2,300$ per unit in LIHEAP funds and has an overall average cost of $\$ 4,500$ per unit. This is because in his particular case, the agency has leveraged other funds that build onto the statewide base levels.

The state has reviewed its operations over the years, has investigated the current research studies, and has even contracted for its own study, to develop its current "Weatherization Priority List." That list establishes an ordering of retrofit measures through a cost effectiveness ranking. That ranking system prioritizes for a low flow shower head, major infiltration, insulation for water heaters, ducts, floors, attics, and sidewalls as well as a variety of other measures. For example flame retention burners for inefficient oil-heated systems and heating system replacements are also allowed. Most local agencies that have supplemental funds perform a combustion test on the heating system. They 
also have the funding flexibility to repair or replace that heating system, as appropriate. Likewise, many of the subgrantees have utility company funds to address electrical demand-side management, such as the installation of compact fluorescent lighting.

\subsubsection{Consumer Education Pllot Project}

Another aspect of the program is the state's Consumer Conservation Education effort. A Consumer Conservation Coordinator was designated in the state office to work with subgrantees to develop more effective consumer education programs. The Opportunity Council in Bcllingham, Washington, has developed a multi-contact client education strategy that includes the use of a negotiated written client action plan. This subgrantee's client education program was developed under a partnership arrangement with Puget Power. A formal evaluation component to that pilot project is now being finalized, and will focus on assessing the impact of energy education on energy savings, program cost-effectiveness, and occupant quality of life. In addition, it will compare the pilot project results with the utility company's traditional programming.

\subsubsection{Staff Training}

As with other programs highlighted in this manual, Washington places a premium on training. The main training emphasis during the current year is in the following areas:

- Integration of blower door protocol

- Infrared Thermography

- High-Density Wall Insulation

- Weatherization of Mobile Homes

- Combustion Appliance Safety Testing

- Consumer Conservation Education

- Direct Crew Training

Coordination with the utility companies has yielded direct benefits in training. The Opportunity Council notes that it can send its staff to training programs offered by the Bonneville Power Administration for field auditors. The utility also provides cenification of the auditors that successfully complete the in-depth training coursework.

The training emphasis was also picked up by the state's Employment Security Department, which recently sponsored displaced timber workers in audit and inspection course training. Now, all subgrantec agencies have lists of the trained displaced workers from which to hire when they have staff vacancies.

In terms of its Major Infiltration standards, the state of Washington has made a commitment to the use of blower door technology. In 1990, the state purchased a blower door for each of its 
subgrantee agencies. Then extensive training was provided to all the agencies, and beginning in 1992, all homes weatherized were required to have pre- and post-blower door tests performed. The state, working with its Technical Development Committee, also set up an Air Leakage Control Protocol. 


\section{NORTHERN TIER COMMUNITY ACTION CORPORATION}

Highlighted Activities: Client Education; Coordination with Local Utility; and Crisis Coordination

\subsection{ADMINISTRATIVE STRUCTURE}

The other programs highlighted in this manual were all state-office focused programs with some local agency practices cited. By contrast the focus of this chapter will be on a local agency, the Northern Tier Community Action Corporation, and particularly its innovative efforts in the client energy education realm. While the state of Pennsylvania does require every local subgrantee agency to develop and implement a client education program, the Northem Tier strategy has been much more comprehensive and complex than what is required by the state.

Northern Tier's 1992 weatherization funding level is $\$ 335,962$ of which $\$ 194,678$ are DOE funds and \$141,284 are LIHEAP funds. At the state level, the budget includes $\$ 12$ million in DOE funds and another $\$ 8.8$ million of LIHEAP funds, for an overall weatherization allocation of $\$ 20.8$ million.

The state provides DOE and LIHEAP funds to its local subgrantees, and requires that the funds be used separately. They cannot be used in the same unit. However, Pennsylvania allows local operators more flexibility with the LIHEAP dollars. This flexibility is in the form of a different requirement for the ratio of labor to support. There is also a higher average per unit cost under the LIHEAP rules. Regardless of funding source, the state requires a blower door and combustion efficiency test on each dwelling weatherized.

\subsection{HIGHLIGHTED ACTIVITIES}

\subsubsection{Client Education}

Recent research studies indicate that a client education process is more likely to succeed if it involves all the staff interacting with the client, seeks to have the client play an active role in the process, and seeks to get a written commitment from the client. In the case of Northem Tier, this is exactly what they have put in place.

The first step in the development process was for Northem Tier to hire an Energy Education Specialist who developed most of the client education forms and procedures now utilized by Northern Tier staff.

In the Northern Tier approach, energy education begins with the first contact the client has with the agency and continues through the audit and installation of weatherization measures to follow-up monitoring of energy usage in the weatherized unit. If energy reduction has not been 
achieved. then additional education sessions for the client are scheduled. The following are the features that distinguish the Northem Tier energy education approach.

1. Northem Tier has developed materials to be used by its staff at each step of the weatherization process.

2. The intake worker provides information about the goals for the weatherization program and refers the client to any other appropriate services for which the client is eligible.

3. The auditor describes to the client the measures that will be installed in the house, and why they have been selected. The auditor also notes any conservation measures that the client has already adopted.

4. Then. there is a specific energy education session, arranged by the Energy Education Specialist, that is tailored to the specific demographics of the houschold. and where the Specialist negotiates a commitment from the client to altain cerrain goals to reduce energy consumption. The energy educator mahes even effort to involve all adult members of the household in this session

5. The instaliers continue the education process by involving the client in the bluner dinis tests. The blower door tests allow the installer to graphically show the client the air leakage areas in the house. The blower door post-test shows the client the reduction in leakage areas that have been achieved after the uf suling work was completed.

6. The afenc, most-work inspector completes the client education process by lating the client around the hoine and asking the client to point out the work thal as renormed. The client is also asked if he/she has any questions about the mezsures installed, or about measures not installed. The client is always encourafes to ask questions and to point out any problems he/she has omened

A special componen of the Northem Tier client education procedure is follow-up. The energy consumption of exh client home is monitored and if there is not a reduction in usage levels, then a follow-up cliens education session is scheduled.

\subsubsection{Utillty Coordination}

Another component of the Northem Tier conservation program is the Low Income Usage Reduction Program (LIURP). This program is a cooperative effor between Northem Tier and two electric utility companies in their service area. The utilities, Pennsylvania Electric Company and West Penn Power Company, have been mandated by the state's public utility commission to provide energy conservation services to their low-income customers. LIHEAP eligibility is not required to qualify for LIURP, but many clients are eligible for LIHEAP services and receive them in addition to LIURP services. With minor variations in scope and purpose to the regular Pennsylvania weatherization program in terms of materials specifications and allowable measures, LIURP activities are the same. Whenever possible. LIURP weatherization is coordinated with the state DOE Weatherization Program 
and LIHEAP weatherization activities. This reduces the costs to both programs. The funds saved can be used to weatherize additional dwellings. So, although LIURP is not applied to every dwelling weatherized with DOE Weatherization Program or LIHEAP funds, it is used in enough of them to extend the reach of both funding sources.

\subsubsection{Crisis Coordination}

There has been a reduction in state LIHEAP funds. In the face of this reduction, Pennsylvania is initiating a new Crisis Interface coordination effort. This initiative is between the state weatherization grantee office and the state's LIHEAP grantee office, the Department of Public Welfare, and will incorporate a new referral mechanism. This program was conceived to streamline the service delivery process and avoid any duplication of effort between various state and local agencies. The County welfare offices will refer crisis clients to the weatherization program. The crisis situation must be addressed within 48 hours, 18 hours if it is considered to be life-threatening. Up to $\$ 300$ of crisis funds will be available to resolve the crisis. If more funds are needed, then the local agency is authorized to use weatherization program funds for the balance of funding needed. Crisis situations that are in excess of the standard $\$ 300$ allotment are automatically prioritized to receive additional weatherization program services. 


\section{CONCLUSIONS}

The programs identified and highlighted in this manual illustrate a variety of ways in which LIHEAP has been able to make a positive contribution to the objective of improved low-income energy conservation. LIHEAP revenues have expanded the reach and increased the flexibility of the DOE Weatherization Assistance Program in California, Illinois, Massachusetts, and Minnesota. LIHEAP funds have contributed to improved client education in Minnesota, Pennsylvania, and Washington. LIHEAP has helped improve staff and technician training in California and Illinois. LIHEAP has helped households living in crisis situations created by the breakdown of their heating systems in New York and Colorado.

Many of the innovative programs used LIHEAP funds for weatherization activities that were not allowed under the previous DOE Weatherization Program rules but which are now permitted. Consequently there may be some states that no longer will use LIHEAP funds for precisely these purposes. The future character of the relationship between DOE and LIHEAP weatherization resources is uncertain and will be determined, in part, by the creative exploration of opportunities created by the new regulations.

It is therefore all the more important to recognize and use the innovative management pattems that have helped create these kinds of programs. Those states that have established strong program leadership, incorporated positive change and self-evaluation into their programs, and empowered their local agencies with appropriate decision-making authority liave been the leaders in the weatherization field. They point the way to a positive future relationship between DOE and LIHEAP weatherization efforts. 


\section{REFERENCES}

Beschen, D.A. and M.A. Brown, 1991. Evaluation Plan for the Weatherization Assistance Program, ORNL/TM-11668/V1, Oak Ridge National Laboratory, Oak Ridge, Tennessee.

Mihlmester, P.E., W.C. Koehler, Jr., M.A. Beyer, M.A. Brown, and D.A. Beschen, Jr., 1992. Characterization of the Weatherization Assistance Prog am Network, ORNL/CON-324, Oak Ridge National Laboratory, Martin Marietta Energy Systems, Inc., Oak Ridge, Tennessee.

Power, M., J.F. Eisenberg, E. Michels, M.J. Witherspoon, and M. A. Brown, 1992. The Scope of the Weatherization Assistance Program: The Weatherized Population and the Resource Base, ORNL/CON-325, Oak Ridge National Laboratory, Oak Ridge, Tennessee.

Brown, M.A., L.G. Berry, R.A. Balzer, and E. Faby, 1993. National Impacts of the Weatherization Assistance Program in Single-Family and Small Multifamily Dwellings, ORNL/CON-326, Oak Ridge National Laboratory, Oak Ridge, Tennessee. 


\section{WEATHERIZATION GLOSSARY}

Air Changes per Hour The number of times the volume of air in a structure will be changed in one at 50 Pascals hour at the induced blower door house pressure of 50 pascals.

Air Sealing

A systematic process of "tightening" a home's structure to reduce uncontrolled heat loss through warm air leakage sites present in the home. It also addresses potential moisture problems in the home. The prevalent technique is to perform this tightening primarily from the interior of the home, known as interior air sealing. Using a variety of materials, such as insulation, caulk, foam, vapor barriers, weatherstripping, etc., workers "seal" the air leakage sites. Air leakage site identification can be aided by the use of diagnostic equipment such as blower doors and infrared scanners, since not all leakage sites are obvious to the unaided eye. Sometimes this process is also known as "house doctoring." Part of the process is to be cautious not to seal a structure too tightly, which could result in health or safety problems for the home's occupants.

Attic Insulation

The process of installing insulation evenly across the unconditioned attic area to achieve desired levels of thermal resistance. Usually, this means installing fiberglass batts or blown cellulose insulation. Both products have manufacturer cited " $R$ " levels (resistance levels) and the more inches of insulation installed the higher the final resistance level. The recommended " $R$ " levels vary by climatic regions of the country. It is common for weatherization programs to install a minimum of $\mathrm{R}-19$, or as much as $\mathrm{R}-38$ in colder regions. The cost effective level of insulation to be added, if any, depends on the existing level of effective insulation in the attic.

Attic Prep

The process of inspecting and preparing an attic area for the installation of insulation. The prep work is directed primarily to safety issues, such as putting barriers around heat-producing sources in the attic (electrical junction boxes, recessed lights, etc.) and placing chutes by the eves to prevent the insulation from blocking needed air ventilation paths.

Balance Heating System

The balance of the heat distribution system assures that all areas served by the same heating plant, or zone of a heating plant receive approximately equal heat.

Blower Door

A door-or window-mounted, (usually) calibrated and variable speed fan that blows air into (pressurizes) or sucks air out of (depressurizes) a house. It has an adjustable frame, usually plastic or fabric, around the fan so that it can fit snugly into most doorways. With the added connection of gauges to measure air flow and pressure, blower doors are used to locate air leakage sites in a home, as well as to quantify the level of leakage. Such leakage measurements are usually expressed in terms of Equivalent Leakage Area, Leakage Ratio, Air Changes per Hour, Cubic Feet per Minute, and/or Cubic Feet per Person or Room. Any one or more of these measuremeits can help to determine levels of air leakage, indoor air quality, and ar nount of sealing work to be performed. This diagnostic tool, used in conjunction with an infrared scanner, produces even more accurate results.

Boiler

An appliance for producing hot water or steam as the medium to distribute heat. 
Building Check \& Job Order Sheet

Carbon Monoxide

Central Heating

CFM 50

CFM Per Person or Per Room

Clean and Tune

Client Energy

Education

Combustion Test

Conduction

Convective Air Flow

Convection Loop
The document used to record the entire scope of the weatherization work that should be done on an individual dwelling unit; along with the estimated and actual costs for the work.

A tasteless, odorless, colorless and deadly gas that is a by-product of incomplete combustion caused by a lack of heat or air to support combustion.

A heating system that includes a heating appliance system and ducts or pipes to distribute heat to more than one area from a central point. Does not include wood stoves, kerosene heaters, space heaters, electric heating units, etc.

Cubic feet per minute of air moving through the structure at 50 pascal house pressure.

An estimate of the cubic feet per minute of fresh air available per person or per room.

A procedure performed on a heating system, which is usually preceded by a combustion efficiency test. The clean and tune can involve a variety of activities to upgrade the efficiency and safe operation of the heating unit, including such actions as pilot and burner adjustment, adjustment of ventilation and combustion, check and reset controls, inspect filters, lubricate motors, flush low water cut-off, check operation of steam and water relief valves, check thermostat, check safety valve, and check thermocouple.

The process utilized by weatherization program staff to inform clients of the ways that they can further reduce energy consumption by their own behavioral patterns. The most effective procedures seem to include multiple interaction and reinforcement with the household residents, and many times the use of a negotiated and written action plan. Researchers have found that if from the initial point of contact with the client to the final contact after the weatherization work is completed, all program staff discuss the energy saving goal and the important role of the client, then the actual potential for preservation of the effectiveness of the measures installed, plus added conservation from actual client behavioral change, is maximized.

The test to determine the efficiency at which a heating appliance is operating at steady state. The actual tests or sequence of tests may vary in conjunction with the type of testing equipment used or the type of heating appliance being tested. Persons performing these tests must be extremely familiar with the instructions included with the type of test equipment being used and must be trained in conducting the tests. In some states, a license is required to perform such tests.

The transfer of heat through a material by molecular movement. In weatherization, reducing heat loss through conduction can include use of insulation.

Air movement where less dense (warmer) air is displaced by more dense (cooler) air. Often expressed by the phrase "hot air rises." Convective air flow can be useful if controlled, as in gravity hot air heating systems, but is more often a contributor to heat loss.

A structural heat-loss that results when there are temperature differences between the inside and outside wall surfaces, and an air movement loop operates within the wall cavity. Particularly present if a stud cavity has no insulation, air in the cavity is heated near the interior surface of the wall, rises, 
Demand Side Management

Distribution System

Domestic Hot

Water (DHW)

Duplex

Dwelling Unit

Eligible Multifamily

Eligible Unit

\section{Exfiltration}

Equivalent

Leakage Area

Furnace

Gas Heating System

Gravity

Household

HOME Program circulates back toward the exterior siding, falls, recirculates back to the warm side, is re-heated, and so on.

The planning and implementation of those utility activities designed to influence customer use of electricity in ways that will produce desired (DSM)changes in the utility's load shape, such as changes in the pattern and magnitude of the utility's load. This theory has resulted in a variety of utilitysponsored programs to redirect their customers' usage patterns, especially in the peak load periods. The ultimate goal for most utilities is to avoid the need to invest in new power plants due to excessive demands on current generating capacity. While mainly an electrically-applied concept, there is some application to gas utilities as well.

The parts of a central heating system that deliver heated transfer medium to the living space, and returns the cooled transfer medium to the appliance for reheating.

In a forced air system this includes the blower, ducts, registers, dampers, and cold air returns.

In a hot water system this includes circulators, supply lines, radiators, and retum lines.

Potable (drinkable) water supplied to the dwelling unit, and heated for washing, bathing, etc. Heating system hot water, is a separate, closed system.

Any structure which consists of two separate dwelling units in one building.

A house, including a stationary mobile home, an apartment, a group of rooms, or a single room occupied as separate living quarters.

A multifamily building qualifies to be weatherized in its entirety when $66 \%$ (50\% for 2 and 4 unit buildings) or more of the total dwelling units in the building are Eligible Units (per DOE rules). However, multiple family units weatherized with LIHEAP funds must be occupied $100 \%$ by eligible clients.

A unit occupied by a household which is categorically eligible or income eligible by DOE and/or LIHEAP standards.

Movement of air out of a building. Often refers to warm air leaving a building because of pressurization, infiltration, wind, stack effect, and/or convective air flow.

Calculation, in square inches, of the total area of all holes and cracks in a structure, to provide one total air leakage calculation.

An appliance for heating air as the medium to distribute heat.

A heating system that uses natural gas or bottled liquid propane gas as fuel.

As opposed to forced circulation, no pumps or circulation blowers are used.

Any individual or group of individuals who are living together as one economic unit for whom residential energy is customarily purchased in common or who make undesignated payments for energy in the form of rent.

A program created under Title II (the Home Investment Partnership Act) of the National Affordable Housing Act of 1990. Provides funds for states to 
Incidental Repairs

Indoor Air Quality (IAQ)

Infiltration

Infrared

Thermography

In Progress Unit

Leakage Ratio

Oil Heating System

Priority List

Retrofit

Seasonal Efficiency

Settling expand the supply of decent and affordable housing for low-income people, and is a program that could be coordinated with a state's weatherization program efforts.

Under DOE rules, refers to the needed repairs that are necessary for the effective performance or preservation of the allowable energy conservation measures installed. Usually, a specific dollar amount is set by a state to limit such incidental repairs.

The recognition that pollutants can exist within a home, and that weatherization workers must be aware of the impact of their work on the quality of the atmosphere within a living space. The presence of pollutants, combined with inadequate ventilation factors, can contribute to a variety of occupant health and safety problems. Therefore, IAQ is a primary concern when workers airscal, or "tighten" homes.

The movement of air into a building. Often refers to cold air coming into a huilding because of depressurization, exfiltration, wind, stack effect, and/or convective air flow.

The science of using radiant energy to determine heat loss characteristics of a huilding. In weatherization usage, an infrared camera or scanner clectronically senses heat radiated by objects and convirts that thermal energy Into Images visible to the human eye. The camera or scanner, similar to a (ancorder in appearance, produces varying shades of black and white images of the building structure. The darker the image, the colder that corresponding surface: the lighter areas are the hotter surfaces. Some scanners can autuniatically record these images on video tape, as well as allow the operator (1) record audio commentary as he/she scans the building. A certain degree of inierpretation skill is needed to properly assess the images being seen by the s anner. Used in conjunction with a blower door, the scanner can provide - aluable data, since the pressurization or depressurization can magnify air le 2 age sites and thermal bypasses.

A usill is usually considered in progress from the time that some materials have been installed until it has been certified as completed.

Measurement of total square inches of infiltration area per 100 feet of surface area.

A heating system that uses heating oil or residual oil as fuel.

The list or rank ordering of installation measures developed by a program to produce the most cost effective energy savings results. Often this is a standardized listing based upon a cost-benefit calculation procedure.

(v) To install energy conservation materials to a pre-existing structure (e.g., they have retrofitted the home by adding R-19 level insulation into the attic area.) (n) To denote a specific installation measure (e.g., the insulation retrofit cost $\$ 365$ to install.)

The overall efficiency of the complete heating system. The Annual Fuel Utilization Efficiency (AFUE) is an approximate measure for the heating appliance itself; it neglects some distribution losses, etc.

Term used to describe effect of insulation depressing over time and, thereby, reducing the overall effectiveness of the insulation installation. This process is primarily the result of using too much air when initially installing the blown- 
Sidewall Insulation

Stack Effect

Steady State

Tenant/Landlord Agreement

Thermal Bypass

Ventilation in insulation--commonly called "flufting." A particular reason to re-inspect some work several months after installation to assess the settling factor, and to determine if there is a recurring settling problem with your installers--either intentionally or unintentionally). The problem also develops in sidewall insulation installations when the cavity is not completely filled. This is avoided if "high-density" insulation is installed.

The process of installing insulation material, usually blown cellulose, into the uninsulated wall stud cavities of a structure to reduce heat loss. Usually achieved by drilling one or more rows of installation holes into the wall, one in each stud cavity. To achieve the most effective results, "high density" wall insulation is recommended. This commonly means that when installing insulation the "pack" should be tight enough that when completed the worker cannot push the insulation around with his/her finger. Technically, it commonly means insulation applied at 3.5 pounds per square foot.

The term for the higher pressure at the top of a structure, the lower pressure at the bottom of a structure, and the neutral pressure somewhere in between, relative to the ambient (surrounding) air pressure. It is caused by the different densities of warmer and cooler air (convective air flow).

The point at which heat into system equals heat out. The system itself is not absorbing any more heat, as determined by noting when the stack temperature becomes constant and distribution pumps or blowers are operating.

A legally-binding contract, usually signed by the tenant, landlord and weatherization agency that specifically cites the role and responsibilities of each party. The basic goal is to ensure that the benefits of the weatherization work accrue primarily to the low-income tenant. A variety of standard clauses can be incorporated, including clauses on landlord's inability to raise rents for specified period of time, eviction prohibition, and landlord required "participation." Participation could take the form of actual cash, provided labor, and/or in-kind contributions. DOE/WAP rules now provide discretion to states to require landlord participation, which is a method to leverage funds, and provide more comprehensive work to rental properties (usually the multifamily rental structures). The agreement should also state the work to be performed by the weatherization agency. The National Consumer Law Center in Washington, D.C. developed a thorough guidance on tenant/landlord agreements and included a number of recommended clauses. A number of states have also developed very detailed procedures and agreement forms, with New York state having a good deal of experience in incorporating landlord contributions.

Similar to a convection loop, this structural heat loss is characterized by heated air traveling up exterior or interior stud cavities and leaking out the top of that cavity to the attic through joints and cracks in the framing, wiring and plumbing holes, etc. Due to their presence inside the structural framing, these types of heat loss sources are sometimes the most difficult to locate.

Means controlled air exchange within a structure. Any structure has to "breathe," and proper ventilation rates must be determined. If the structure requires more interior/exterior air exchanges, then there are mechanical and non-mechanical options for increasing those rates, with most common technique being the installation of roof, soffit, and/or gable vents. 



\section{RECOMMENDED PUBLICATIONS AND RESOURCES}

\section{GENERAL OVERVIEW}

An Index of Joint State-Utility Energy Programs. The Alliance to Save Energy, April 1990.

"Introduction to Demand Side Management," Paper presented by Rana Belshe of Energy Exchange/Conservation Connection and Paul Berkowitz, Wisconsin Energy Conservation Corporation; Weatherization 1991: USDOE Midwest Technical Conference, June 4-6, 1991.

Making Residential Weatherization Programs More Cost Effective: A Guide for Program Managers, The Alliance to Save Energy, October 1989.

Putting It All Together: A Resource Guide for Coordinated State-Utility Low Income Energy Programs, The Alliance to Save Energy, March 1990.

"Setting Priorities for Weatherization: Beyond Simple Payback," Mary Beth Zimmerman, Home Energy, July/August 1990.

State Energy Efficiency Programs Improvement Act of 1990.

The Energy Policy and Conservation Act of 1975 (Public Law 94-163)

The State-of-the-Ant of Low-Income Weatherization: Past. Present, and Future; Schlegel, Jeffrey; Wisconsin Energy Conservation Corp.; 1990.

Weatherization Assistance Program Briefing Book; USDOE; July, 1990 (an overview to WAP regulations and program administration, though some citations are outdated. Does contain some good annotated resource references).

Weatherization Assistance Program for Low-Income Persons; Final Rule. 10 CFR Part 440. USDOE, January 27, 1984.

Weatherization Assistance Program for Low-Income Persons; Interim Rule, 10 CFR Part 440 , USDOE, January 4, 1985.

Weatherization Assistance Program for Low-Income Persons; Proposed Rule, 10 CFR Part 440, USDOE, March 4, 1993

Weatherization References and Resources, Sheladia Associates, Inc., Rockville, MD; May, 1987 (a resource guidebook for weatherization program managers prepared for US DOE).

\section{CLIENT EDUCATION}

An Evaluation of the Michigan Low-Income Weatherization Energy Education and Incentives Program, Final Report, Kushler \& Witte, Michigan Public Service Commission, Lansing, Michigan, December 1989.

Energy Education Manual. Michigan Dept. of Labor/Bureau of Community Services, Lansing, Michigan, 1989 (a comprehensive manual develnped by Bonnie Esposito for the state WAP).

Results of the 1991 Client Education Needs Assessment Information Request. USDOE, February 1992 (provides survey results of what state WAP offices were doing with client energy education). 


\section{MOBILE HOMES}

HEICA and Mobile Homes: Special Considerations for Special Housing Stock; Kinney, Belshe \& Wilson for N.Y. State Dept. of Public Service, April 1988.

Manufactured Housing/Mobile Homes Weatherization Resource Guide, U.S. Dept. of Energy, Office of State \& Local Assistance Programs, Weatherization Assistance Program, March 1985.

Mobile Home F Handbook, Energy Resources Center, The University of Illinois at Chicago. January . .

Mobile Home Weatherization: A Final Report, The Underground Space Center. Minnesota Building Research Center, University of Minnesota, March 1989.

Mobile Home Ucatherization: A Guidebook for Installers, Bonneville Power Administration, August 1986

Mobile Home Usutherization: A Status Reperl. The National Center for Appropriate Technolog!. 11arin 1985.

Mobile Hums $u$ sithenzation Measures Testing \& Training: The CMFERT Project, Solar Energy Rescarh Insutute, Golden, CO., 1989.

Mobile Hum: Us uhenzation Research Project: Final Summary Report, Corporation for Ohio Appalachuan Ixvelopment. Energy Conservation Program, March 1989.

Weathenzzitun Muses a Difference: Saving Electricity in Mobile Homes, Bonneville Power Administration. August 1986.

Weatheru ix Jivuc Nlobile Home, Bonneville Power Administration, August 1986.

Your Mutuls Hlime Encrgy \& Repair Guide, Satum Resource Management, Helena, Montana, 1991.

\section{MOISTURE ISSUES}

"Assessing and Silving Residential Moisture Problems," J. Lstiburek and Dr. G. Tsongas, Presentation Paper at Affordable Comfort V Conference, 1991.

Moisture and Home Energy Conservation: How to Detect. Solve and Avoid Related Problems, USDOE. Sept 1983.

"Moisture Problems in Existing Residences," Dr. George A. Tsongas, Portland State University, Presentation Paper at National USDOE Weatherization Conference, 1989.

\section{MECHANICAL/DISTRIBUTION ISSUES}

"A Million Miles of Ducts: Duct Sealing Update," Brian Coyne. Home Energy, March/April 1992 (examines "science" of duct sealing, an area that accounts for 10\%-15\% of a home's total air leakage).

"Common Trouble Spots When Sealing Duct Work," T. Lehahan, Presentation Paper at Affordable Comfor V Conference, 1991. 
Duct Doctoring: Diagnosis and Repair of Duct System Leaks, J. Cummings, J. Tooley, and N. Moyer, Florida Solar Energy Center, 1992 (a training manual by the pioneers in the field of duct sealing).

Gas Retrofit Manual: Auditing Techniques and Efficiency Improvements for Residential Heating Systems, Alliance to Save Energy, September 1986 (a comprehensive manual to inspecting heating systems, analyzing efficiency, and installing appropriate retrofits).

"House Pressure Balancing As a Part of Weatherization," T. Lenahan, Presentation Paper at Affordable Comfort V Conference, 1991.

"Potential For Retrofitting Residential Heating Systems to Improve Efficiency," A.C.S. Hayden and R.W. Braaten, Presentation Paper at Affordable Comfort V Conference, 1991.

Residential Heating Systems, Cutter Information Corp., 1100 Massachusetts Ave., Arlington, MA 02174, (617) 648-8700 (a 54-page overview of heating systems).

Weatherization Technical Manual, Commonwealth of Massachusetts, Executive Office of Communities and Development, 1988 ( $a$ very thorough review of the retrofit measures that are allowable under the state's weatherization program).

\section{RESEARCH STUDIES}

Air Infiltration Leakage Sources Project, Bonneville Power Administration, March 1986 (final report of a project to reduce air infiltration using "house doctoring" techniques. BPA followed with its House Tightening Manual--see citation \#51).

An Assessment of Energy Savings Resulting from 2-Wall and 4-Wall Insulation; Kushler \& Witte, Michigan Public Service Commission; December 1989.

An Early Assessment of the Home Repair and Weatherization Component of the Michigan Energy Assurance Program, M. Kushler and P. Witte, Michigan Department of Commerce, March 1986 (reviews energy/cost findings of a pilot effort by state that performed two levels of weatherization work: "basic" weatherization and weatherization plus major home repair).

An Evaluation of the Michigan Low-Income Weatherization Energy Education and Incentives Program, Final Report, Kushler \& Witte, Michigan Public Service Commission; December 1989.

Characteristics of the Weatherization Assistance Program Network; Oak Ridge National Laboratory; February, 1992.

Evaluation Plan for the Weatherization Assistance Program; Beschen and Brown, U.S. Dept.of Energy and Oak Ridge National Laboratory; August 1991. (outlines the 5-year multicomponent national weatherization program evaluation project).

"Evaluation Updates," paper presented by Jeff Schlegel, Wisconsin Energy Conservation Corp., at 1991 Region V Midwest Technical Conference (summarizes results of several recent studies of weatherization activities).

"Fifty Million Retrofits Later," Sam Cohen, Home Energy, May/June 1990 (a brief summary of citation \#33).

Integrating Analytical Tactics into New York State's Weatherization Assistance Program: Project Findings; Synertech Systems Corp., September 1987 (review'ed project to utilize blower doors and other analytical tools in the weatherization of 100 dwellings). 
Looking Past the First Year: Do the Savings Last?; U.S.Dept.of Energy/Existing Buildings Efficiency Program; Wisconsin Energy Conservation Corp.; Narum, Pigg, and Schlegel; March 1992.

Low-Income Weatherization: Who Benefits? Final Report. Volume 1: Technical Report, RCG/Hagler, Baillly, Inc., January 1991. (study of multi-family/landlord issues in Milwaukee).

Marketing and Design of Residential Energy Conservation Programs for the Elderly; Berry, Schweitzer and Freeman, Oak Ridge National Laboratory, February 1988 (study examined 39 programs that served the energy needs of the elderly, and discusses marketing and interagency coordination issues).

Measured Energy Savings and Economics of Retrofitting Existing Single-Family Homes: An Update of the BECA-B Database; Cohen, Goldman and Harris, Lawrence Berkeley Laboratory; Volumes I \& II; February, 1991 (this is a thorough compilation study that summarizes energy and cost data from multiple local studies across the nation).

Pilot Study Results for the Michigan Oil Fumace Fuel Efficiency and Retrofit Program, M. Kushler and P. Witte, Michigan Department of Commerce, October 1985 (reviews energy cost findings of a pilot project to install flame retention burners).

Results of the Michigan Natural Gas Fumace Retrofit Pilot for Low-Income Households, M. Kushler and P. Witte, Michigan Department of Commerce, April 1987 (reviews energy/cost findings of a pilot project that installed several different natural gas retrofits).

Weatherization Assistance for Low-Income Households: An Evaluation of Local Program Performance, Oak Ridge National Laboratory, August 1987.

The M200 Enhanced Low-Income Weatherization Demonstration Project. Underground Space Center, Minnesota Building Research Center, University of

Minnesota, February 27, 1990 (cites findings of a project that weatherized 200 single-family homes according to an "enhanced protocol." The protocol was based on a decentralized decision-making process, which gave the work staff the tools and responsibility for diagnosing the needs of each house).

The National Fuel End-Use Efficiency Field Test: Energy Savings and Performance of an Improved Energy Conservation Measure Selection Technique, Oak Ridge National Laboratory, March 1991. (Review's use of an automated audit system).

\section{WARM ROOM CONCEPT}

Warm Room: Applications, Recommendations, and Resources, Alliance to Save Energy, March 1987.

\section{INDOOR AIR QUALITY}

Home Weatherization \& Indoer Air Pollutants, Bonneville Power Administration, November 1984.

The Inside Story: A Guide to Indoor Alr Quality, U.S. Environmental Protection Agency, EPA/400/1-88/004, Sept. 1988. 


\section{MULTIFAMILY/RENTAL}

Michigan Multifamily Weatherization Research Project (Draft); T. Wilson, Residential Energy Conservation Consulting Group, Fairchild, Wisconsin, December 1990 (though never finalized, this document thoroughly reviews many of the difficult issues associated with the weatherization of multifamily structures).

The Renters Handbook for Weatherization Assistance Programs Grantees and Subgrantees, USDOE, August 1984 (this is still the latest USDOE guide on all rental weatherization rules).

\section{BLOWER DOORS}

"Blower Doors \& Weatherization," USDOE, Washington, D.C. (a brief 4-page overview of topic).

"Building Analysis Equipment: Introduction to the Blower Door and Infrared Thermography," paper presented by G.H. Runevitch and T. Calhoun, Corporation for Ohio Appalachian Development, July 1990, 1990 Midwest Technology Transfer Conference.

"How Effective Are Blower Doors?", K. Butterfield, Home Energy, January/February 1989.

"Practical Techniques for Residential Thermography," Energy Auditor \& Retrofitter, Jan/Feb 1986.

The Blower Door: A New Tool for Weatherization, Steve Wolfe, PhD., introductory document produced for state of Michigan weatherization program, September 1986.

Note: Many blower door manufacturers have produced very informative training documents and/or training videos.

\section{INFRARED SCANNING}

A Survey of the Use of Infrared Thermography in the Dept. of Energy's WAP, John R. Snell, Jr., March 1989 (a good overview of the uses and benefits of incorporating infrared technology into the weatherization program. Mr. Snell is a well-recognized infrared thermography trainer).

"Infrared Scanners \& Weatherization," USDOE, Washington, D.C. (a brief 4-page overview of topic).

Michigan Infrared Scanner Inspection Project Overview, Michigan Dept.of Labor, June 1988. Paper outlines contracted use of infrared scanning to document completeness of sidewall insulation installations in weatherization program.

\section{INTERIOR AIR SEALING}

Air Sealing Homes for Energy Conservation; Energy, Mines and Resources Canada, 580 Booth Street, Ottawa, Ontario-Canada K1A-OE4, (613) 995-1118 (a very comprehensive air sealing manual with ready-to-use worksheets for field workers).

Contractor's Guide to Finding and Sealing Hidden Air Leaks, Environmental Science Department, Massachusetts Autobahn Society, Lincoln, MA 01773, (617) 259-9500 (a 37page manual designed to help workers find and seal the most common hidden air leaks). 
House Tightening Manual for Homeowners and Weatherization Contractors, Bonneville Power Administration (BPA contract No. DE-AC79-83BP13301). October 1985 (this 51page manual resulted form BPA's earlier air leakage repair project's findings--see citation $39 J$.

"In Search of the Missing Leak," M. Blasnik and J. Fitzgerald, Home Energy, November/December 1992 (two nationally recognized air sealing innovators review the latest field issues and techniques).

The Airtight House, J. Lischkoff and J. Lstiburek, Iowa State University, EES Bldg., Haber Road, Ames, Iowa 50011, (515) 294-8815, \$14.95 (though it talks about a new construction technique, there are many retrofit appropriate concepts).

\section{AUTOMATED ENERGY AUDITS}

"Computing Energy Savings: A Software Overview," A. Meier and L.Rainer, Home Energy, September/October 1991 (article reviews several software programs and discusses the overall issue).

The North Carolina Field Test Computerized Audit: Description and Operation (Draft), M.B. Gettings, Oak Ridge National Laboratory, October 1990 (describes preliminary version of a computerized audit system to determine cost effective measures selections).

The WECC Energy Audit System, Wisconsin Energy Conservation Corporation, Madison, Wisconsin (this automated system combines home auditing with program administration, work order development, reporting and evaluation. It was designed for the Wisconsin WAP).

The Whole House Energy Audit, State of Illinois WAP automated audit.

\section{TRAINING VIDEOS/COMPUTER PROGRAMS}

"Air Sealing Houses," "Minnesota Case Study," "Indiana Case Study", "MAD-AIR vs. The Duct Busters," and "Mobile Home Weatherization." This 5-tape set is available from The Energy Conservatory, 5158 Bloomington Ave. S., Minneapolis, MN 55417, (612) 827-1117 (the emphasis of these tapes is on how to treat "houses as a system of interacting components." The information and techniques shown represent state-of-the-art practices).

"Blower Doors," USDOE, Washington, D.C., 1989 (this is a computer-based/interaction videodisc training program that provides a very "life-like" presentation on the subject of blower door theory and usage. It does take special equipment to show this program. USDOE does have an equipment/disc package that can allow for the program to be mailed around the country. Call the WAP Headquarters in Washington to determine availability).

"Blown Insulation for Sidewalls," Nebraska Energy Office, 9th Floor-State Capitol, Box 95085, Lincoln, NE 68509 (a 15-minute overview of sidewall insulation techniques).

"Furnace Safety \& Efficiency: Diagnosing \& Repairing Forced Air Combustion Heating Systems," Northwest Montana Human Resources, Inc., P.O. Box 1058, Kallspell, Montana 59903-1058, (406) 752-6565 (a 2-hour comprehensive training, comes with a detailed manual).

"Indoor Air Sealing," Sheltech Associates, P.O. Box 399, LaConner, WA 98257, (206) 466 4319 (60-minute training video that is a good solid overview of topic, done with a humorous easy-going approach. About 1988 vintage). 
"Interior Air Sealing: The Energy Saving Technique," State of Michigan Weatherization Program. Available through UPCAP, Inc., P.O. Box 606, Escanaba, Michigan 49829 (a 28minute training video, with a good combination of technical information and interesting presentational style).

"Minneapolis Blower Door Training Video," The Energy Conservatory, 5158 Bloomington Ave. S., Minneapolis, MN 55417, (612) 827-1117 (this is a 2-hour introduction to the blower door and its usage. Even though this is done by a commercial manufacturer, the facts/techniques presented are useful for any blower door technician. First 5 minutes alone worth price of tape).

"Mobile Home Floor Retrofits for Energy Efficiency," Saturn Resource Management, 11 N. Davis Street, Helena, Montana 59601, (406) 443-3433 (basic review of inspection and treatment of mobile homes).

"Mousing Through the Basement," Lester S.Shen, Home Energy, September/October 1991 (article highlights the interactive mechanical systems computer training program designed for trainees at the state of Minnesota training center. Includes information on ordering the program).

"The House as a System," Target Communications, 4248 Ridge Lee Road, Amherst, NY 14226, (716) 831-9931 (one of a series of videos on total house concept).

"The Weatherization Team and You," USDOE, Washington, D.C., 1990 (short video to use with staff or clients, developed for use within WAP. Has a pamphlet for complementary use).

"This Cold House," State of Massachusetts, 1989 (a short client education video used with clients).

"Weather or Not Game Show," USDOE, Washington, D.C., 1990 (companion video to ...Team and $\mathrm{You}$ ).

\section{PERIODICALS}

(Check with Publishers for latest rates):

Air Conditioning, Heating and Refrigeration News; Business News Publishing Co., P,O, Box 2600, Troy, MI 48007, (313) 362-3700; published 52 times/year; $\$ 54$ per year.

ASHRAE Journal; 1791 Tullie Circle NE, Atlanta, GA 30329; monthly magazine; $\$ 39$ per year.

Energy Conservation Digest; P.O. Box 20754, Seattle, WA 98102; (206) 322-8387; published 24 times/year.

Energy Design Update; monthly, \$157/yr., P.O. Box 1709, Ansonia Station, N.Y., N.Y. 10023.

Energy Exchange; quarterly, \$35/yr., P.O. Box 1075, Syracuse, N.Y. 13201-1075; (315) 4223895

The Energy Report; 1401 Wilson Blvd., Suite 900, Arlington, VA 22209; (800) 424-2908; published weekly; $\$ 535$ per year.

Energy Today; Trends Publishing, Inc., National Press Bldg., Washington, D.C. 20045; $\$ 595$ per year. 
Home Builders' Energy Update; quarterly, free, Minnesota Dept. of Public Service, Energy Division, 900 American Center Building, 150 East Kellogg Blvd., St. Paul, MN 55101.

Home Energy Magazine; bimonthly; 2124 Kittredge St., No.95, Berkeley, CA. 94704-9942; (510) 524-5405: \$49 per year.

Indoor Air Quality Update: 37 Broadway, Arlington, MA 02174, (617) 648-8700; monthly newsletter, \$207 per year.

The Joumal of Light Construction; P.O. Box 686, Holmes, PA 19043; (800) 345-8112; monthly; $\$ 27.50$ per year.

The Oil Daily: 1401 New York Ave., NW, Suite 500, Washington, D.C. 20005; (800) 621$0050 ; \$ 447$ per year.

Solar Energy Incelligence Report; Business Publishers Inc., 951 Pershing Dr., Silver Spring, MD 20910-404: (301) 587-6300; published bi-weekly; \$335 per year.

\section{RESOURCES FOR INFORMATION}

Affordable Comlun. Inc., 100 N. 17th Street, 3rd Floor, Philadelphia, PA 19103, (215) 5633761. Alln Linda Wigington (sponsoring group for annual (March) Affordable Comfort Conference)

Alliance to Sue Eskrgy, 1725 K Street NW, Suite 914, Washington, D.C. 20006, (202) 857 0666.

American Council for an Energy-Efficient Economy, 2140 Shattuck Ave., Suite 202, Berkeley, CA 4\$7(4. (510) 549-9914 (ask for publications catalogue).

American Sixicly of Heating, Refrigerating and Air-Conditioning Engineers, Inc., 1791 Tullie Circle. NE. Allanta, GA 30329-2305, (404) 636-8400 (ask for catalog of publications).

Consenjuon and Rencuable Energy Inquiry and Referral Service (CAREIRS), USDOE, P.O. Box 89(x). Silier Spring, MD 20907, (800) 523-2929 (provides general packets of information un energ' conservation and renewable energy topics).

Cutter Information Corp., 37 Broadway, Arlington, MA 02174-5539, (617) 648-8700 (has publications listines for many residential energy conservation topics--same publishers for Energy Desisn ('ousule).

Economic Opportunity Research Institute, 733 15th Street, Suite 700, Washington, DC, 20005, (202) 628-4911

Insulation Contractors Association of America, 15819 Crabbs Branch Way, Rockville, MD 20855-2635, (301) 590-0030 (offers some technical publications for sale).

National Appropriate Technology Assistance Service (NATAS) U.S. Department of Energy, P.O. Box 2525, Butte, Montana 59702-2525 (800) 428-2525

National Association of Community Action Agencies, 1826 18th Street, N.W., Washington, D.C. 20009 , (202) 265-7546.

National Association for State Community Services Programs, 444 North Capitol St. NW Washington, DC, 20001, (202) 624-5865. 
National Association of State Energy Officials, 613 G. Street, N.W., 5th Floor, Washington, D.C. $20001,(202) 639-8749$.

National Center for Appropriate Technology, P.O. Box 3838, Butte, Montana 59702, (406) 494-4572.

National Consumer Law Center, 236 Massachusetts Ave., Washington, D.C. 20002, (202) 5436060 .

National Energy Information Center, USDOE, Forrestal Bldg., EI-22-Room 1F048, 1000 Independence Ave., SW, Washington, D.C. 20585, (202) 586-8800 (provides data on energy production, consumption, prices and supplies).

National Energy Conservation Association, 1470 Wilson Place, Winnipeg, Manitoba R3T 3N9. Puts out technical bulletins on a variety of topics.

National Renewable Energy Laboratory, 1617 Cole Blvd., Golden, CO 80401, (303) 231 7000 .

Oak Ridge National Laboratory, P.O. Box 2008, Oak Ridge, TN 37831, (615) 574-1000 
Appendix A

List of Showcase Programs 


\section{LISTING OF SHOWCASE PROGRAMS}

\section{CALIFORNIA}

Department of Economic Opportunity 700 North 10th Street, Room 272

Sacramento, CA 95814

Attn: Michael Micciche

(916) 323-8694

FAX (916) 327-3153

\section{COLORADO}

Colorado Division of Housing

1313 Sherman Street, Room 323

Department of State

Denver, CO 80203

Attn: Jeffrey Ackermann

(303) $866-4652$

FAX (303) 866-4485

The Energy Resource Center

5735 A. Industrial Place

Colorado Springs, CO 80916

Attn: Winnie Zeisel

(719) 591-0772

FAX (719) 591-0885

\section{ILLINOIS}

Office of Human Services

Division of Economic Opportunity

Illinois Department of Commerce

620 E. Adams Street, 4th Floor

Springfield, IL 62701

Attn: Wayne Curtis

(217) 524-8024

FAX (217) 782-1206

\section{MASSACHUSETTS}

Executive Office of Communities \& Dev.

Bureau of Energy Programs

100 Cambridge Street, Room 1803

Boston, MA 02202

Attn: Ken Rauseo

(617) 727-6964

FAX (617) 727-4259
MASSACHUSETTS (cont'd)

South Middlesex Opportunity Council, Inc. Energy and Financial Assistance Programs

354 A Waverly Street

Framingham, MA 01701

Attn: Arthur Wilcox

(508) 620-1230

FAX: (508) 620-2310

\section{MINNESOTA}

Department of Jobs \& Training

Community Based Services

390 N. Robert Street

St. Paul, MN 55101

Attn: Mark Kaszynski

(612) $297-2590$

FAX (612) 296-0994

Ramsey Action Programs, Inc.

Energy Conservation Division

Park Square Court

215 E. 16th Street

St. Paul, MN 55101

Attn: Paul Vielhaber

(612) $482-8260$

FAX (612) 482-9003

\section{NEW YORK}

Division of Economic Opportunity Department of State

162 Washington Avenue, 7th Floor

Albany, NY 12231

Attn: Rick Gerardi

(518) 474-5700

FAX 518-486-4663

NEW YORK (cont'd)

Northfield Community LDC

191 Prot Richmond Avenue

Staten Island, NY 10302

Attn: Joan Catalano

(718) 442-7351

FAX (718) 981-3441 
NORTHERN TIER COMMUNITY

ACTION CORP.

Northern Tier Community Action Corp.

P.O. Box 389

135 W. 4th Street

Emporium, PA 15834

Attn: Kenneth Straub

(814) $486-1161$

PENNSYLVANIA

Bureau of Human Resources

Department of Community Affairs

358 Forum Building

Harrisburg, PA 17120

Attn: James Etta Reed

(717) $787-7301$

FAX (717) 787-6074

\section{WASHINGTON}

Housing Division

Department of Community Development

906 Columbia Street, SW

P.O. Box 48300

Olympia, WA $98504-8300$

Attn: Kathy Kreiter

(206) 586-6459

FAX (206) 586-5880

The Opportunity Council

314 E. Holly, 2nd floor

P.O. Box 159

Bellingham, WA 98225

Attn: Michael Karp

(206) 734-5121

FAX (206) 676-2142

FAX (518) 474-4663 


\section{Appendix B}

LIHEAP Information Memorandum 


\section{LOW-INCOME HOME ENERGY ASSISTANCE}

Information Memorandum
US. Department of

Heakth and Human Services

Administration for Crildren and Families

Ofíce of Community Services

370 LEnfant Promenade, S.W.

Washington, D.C. 20447

Transmittal No. LIHEAP-IM-93-20

Date $6 / 4 / 93$

TO:

SUBJECT:

RELATED

REFERENCES

PURPOSE :

CONTENT:
LOW INCOME HOME ENERGY ASSISTANCE PROGRAM (LIHEAP) GRANTEES AND OTHER INTERESTED PARTIES

Rules for Use of LIHEAP Weatherization Funds Versus Department of Energy (DOE) Low-Income Weatherization Assistance Program (LIWAP) Funds

Low Income Home Energy Assistance Act of 1981 (title XXVI of the Omnibus Budget Reconciliation Act of 1981, Public Law 97-35, as amended); HHS block grant regulations as amended, 45 CFR Part 96; Energy Conservation in Existing Buildings Act of 1976 (title IV of the Energy Conservation and Production Act, Public Law 94-385), as amended); Final Rule, Weatherization Assistance Program for Low-Income Persons (41 FR 12514), 10 CFR Part 96.

To inform grantees of and to clarify the similarities and differences between the weatherization programs administered by the Department of Health and Human Services (HHS) under the Low-Income Home Energy Assistance Program and the Department of Energy under the Low-Income Weatherization Assistance Program.

Under the Low Income Home Energy Assistance Program (IIHEAP) administered by the Department of Health and Human Services, grantees may use up to 15 percent of the funds allotted or available to them for low-cost weatherization or other energyrelated home repairs. With a waiver from HHS, this amount may be increased to up to 25 percent. The Department of Energy operates the Low-Income Weatherization Assistance Program (IIWAP). Many grantees will have the same agency operate both the LIHEAP and DOE weatherization programs, using essentially the same guidelines. The purpose of this memorandum is to advise grantees that there are some situations under which this should not be done.

The DOE weatherization statute anc regulations apply specifically to LIWAP, and the IIHEAP statute and regulations apply to LIHEAP. However, to promote consistency in their weatherization programs, LIHEAP grantees may choose to use DOE weatherization provisions as guidelines in 
administering their LIHEAP weatherization programs, except when they conflict with the IIHEAP statute and regulations. In many cases, the IIHEAP statute and regulations are silent as to how the funds are to be administered. In such cases, there is no objection to using DOE weatherization guidelines for LIHEAP weatherization activities. However, there are specific differences between the requirements of the two programs in several instances. Grantees must adhere to the LIHEAP requirements when using IIHEAP funds for weatherization when they conflict with DOE weatherization requirements.

Section 2605 (b) (1) of the LIHEAP statute provides that the state will:

use the funds available under this title for the purposes described in section 2602 (a) and otherwise in accordance with the requirements of this title, and agrees not to use such funds for any payments other than payments specified in this section;

The LIHEAP statute prohibits the use of funds unless directed to benefits for households identified as eligible for LIHEAP. The LIHEAP statute requires in section 2605 (b) (2) that the grantee will:

make payments under this title only with respect to--

(A) households in which 1 or more individuals are receiving--

(i) aid to families with dependent children under the state's plan approved under part $A$ of title IV of the social security Act (other than such aid in the form of foster care in accordance with section 408 of such Act);

(ii) supplemental security income payments under title XVI of the Social Security Act;

(iii) food stamps under the food stamp Act of 1977 ; or

(iv) payments under section 415, 521, 541 , or 542 of title 38 , United States code, or under section 306 of the Veterans' and Survivors'

Pension Improvement Act of 1978; or

(B) households with incomes which do not 
exceed the greater of--

(i) an amount equal to 150 percent of the poverty level for such state; or

(ii) an amount equal to 60 percent of the state median income;

except that no household may be excluded from eligibility under this subclause for payments under this title for fiscal year 1986 and thereafter if the household has an income which is less than 110 percent of the poverty level for such state for such fiscal year.

Several differences exist between LIHEAP and DOE weatherization requirements. Following are situations which HHS has identified in which the IIHEAP statute differs with DOE policies. In such cases, LIHEAP requirements must be followed:

1. DOE regulations for administering its Low Income Weatherization Assistance Program (IIWAP) allow weatherization repairs to be made to multi-unit rental dwellings when at least $66-2 / 3$ per cent (or $2 / 3$ ) of the households residing within the building are eligible for LIWAP (or 50 per cent for a twoor four-unit building). Several grantees have inappropriately used the DOE "2/3 rule" for LIHEAP. The Department of Health and Human Services (HHS) has found this to be a clearly erroneous interpretation of the LIHEAP statute, based on the fact that the LIHEAP statute limits LIHEAP benefits to those households that are eligible for LIHEAP. (We, of course, would consider any grantee's arguments to the contrary, under the "clearly erroneous" standard.) Many states have adopted a practice whereby they either use LIHEAP funds for the $2 / 3$ of the units which are eligible for LIHEAP and DOE funds for the remaining units or they use DOE funds for the entire building.

2. The IIHEAP statute requires that persons who are denied benefits or whose applications are not acted upon with reasonable promptness have a right to a fair hearing. The DOE program does not have such a requirement.

3. LIHEAP considers the cost of conducting financial audits to be an administrative cost (unless a grantee were to successfully argue 
otherwise and we found their interpretation not to be "clearly erroneous"). However, DOE has provided in section 440.18 (c) of its final rule dated March 4, 1993, that the costs of LIWAP financial audits may be regarded as a separate program support cost and is not to be regarded as an administrative cost.

4. DOE allows the weatherization of a vacant unit if the landlord certifies that, within 180 days, the unit will be occupied by an eligible low income household. Under section 2605 (b) (2) of the IIHEAP statute, which limits LIHEAP benefits to eligible households, LIHEAP funds may not be used for weatherization unless the specific household intended to occupy the unit has been identified and certified as eligible for LIHEAP prior to the work being done.

5. The unit upon which eligibility is based is different for the LIHEAP and DOE weatherization programs. The unit upon which IIHEAP eligibility is based is the "household." Section 2603 of the LIHEAP statute defines "household" as

any individual or group of individuals who are living together as one economic unit for whom residential energy is customarily purchased in common or who make undesignated payments for energy in the form of rent.

The unit upon which DOE weatherization eligibility is based is the "dwelling unit." Section 440.3 of the DOE regulations defines "dwelling unit" as

a house, including a stationary mobile home, an apartment, a group of rooms, or a single room occupied as separate living quarters.

The amendments to the DOE weatherization regulations issued as a Final Rule on March 4, 1993 (58 FR 12514) defines "separate living quarters" as

living quarters in which the occupants do not live and eat with any other 
persons in the structure and which have either direct access from the outside of the building or through a common hall or complete kitchen facilities for the exclusive use of the occupants. The occupants may be a single family, one person living alone, two or more families living together, or any other group of related or unrelated persons who share living arrangements, and includes shelters for homeless persons.

6. DOE allows its grantees to spend 5 percent of their allotment on training and education, which is considered not to be an administrative cost. IIHEAP funds which are used for training and technical assistance should normally be considered as administrative costs and thus subject to the 10 percent statutory cap on administrative costs.

7. Under DOE weatherization, the average cost spent on weatherizing a home may not exceed $\$ 1600$. IIHEAP does not have such a limit. Consequently, many states use IIHEAP funds for more expensive activities, such as replacing a furnace.

Grantees should be certain to follow the statutory and regulatory guidance of LIHEAP in the above instances and any other instances in which the DOE weatherization requirements conflict with the LIHEAP requirements. 
INQUIRIES TO:
Janet M. Fox, Director

Division of Energy Assistance Office of Community Services, ACF, HHS 370 L'Enfant Promenade, S.W. Washington, D.C. 20447

Telephone: (202) 401-9351

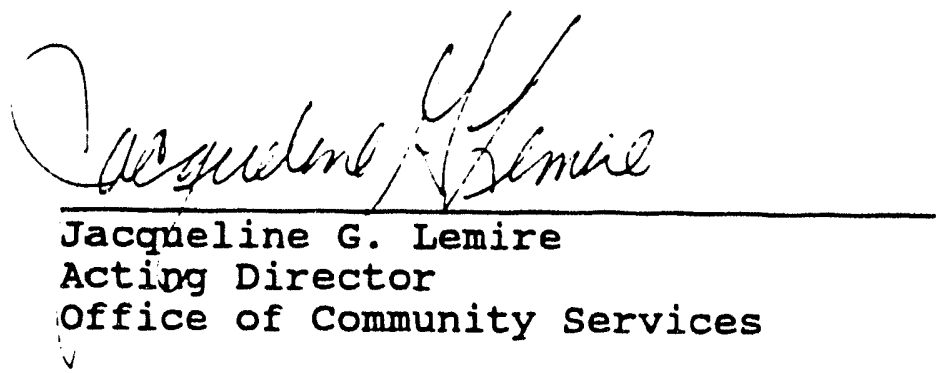




\section{INTERNAL DISTRIBUTION}

1 M.A. Brown, 4500 N, MS 6206

2 T.R. Curlee, 4500 N, MS 6205

3-8 S.A. Surdam, 4500N, Room H11-D

9 ORNL Patent Office

10 J.W. Cooke, 4500 N, MS 6269
11 Central Research Library

12 Document Reference Section

13-15 Laboratory Records (3)

16 Laboratory Records - RC

\section{EXTERNAL DISTRIBUTION}

17-21 Leon Litow, Department of Health and Human Services 4202 Falcon Wood Place, Burtonsville, Maryland 20866

22. Office of Assistant Manager for Energy Research and Development, DOE Oak Ridge Field Office, P.O. Box 2008, Oak Ridge, TN 37831-6269

23-24 OSTI, U.S. Department of Energy, P.O. Box 62, Oak Ridge, TN 37831

25-29 J. Van Vlandren, U.S. Department of Energy, EE-532, 1000 Independence Ave., S.W., Washington, DC 20585 

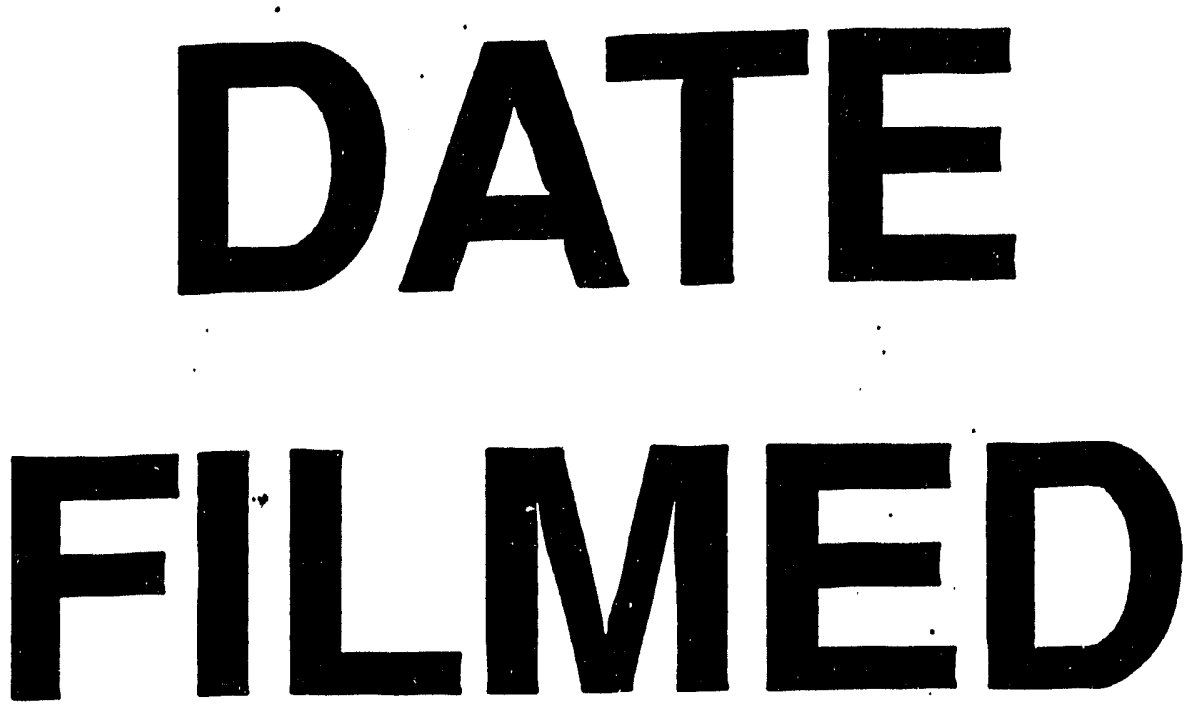

$1 / 6 / 94$
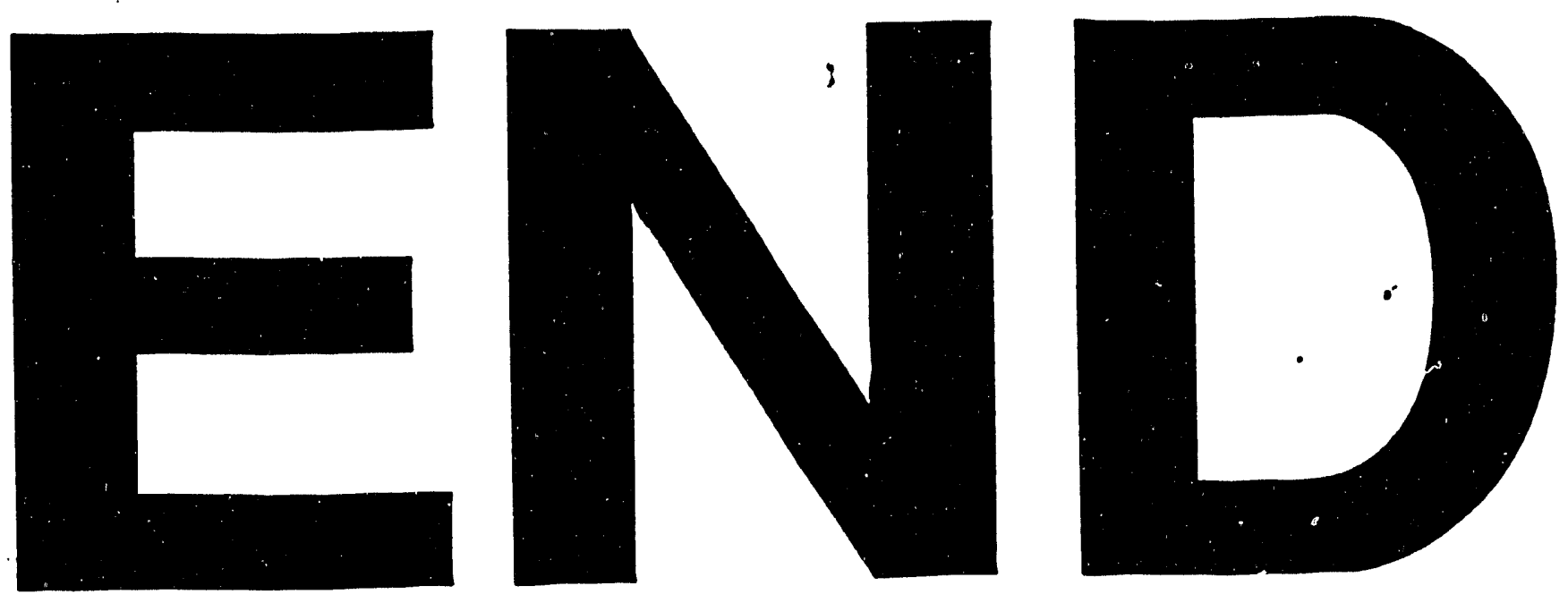

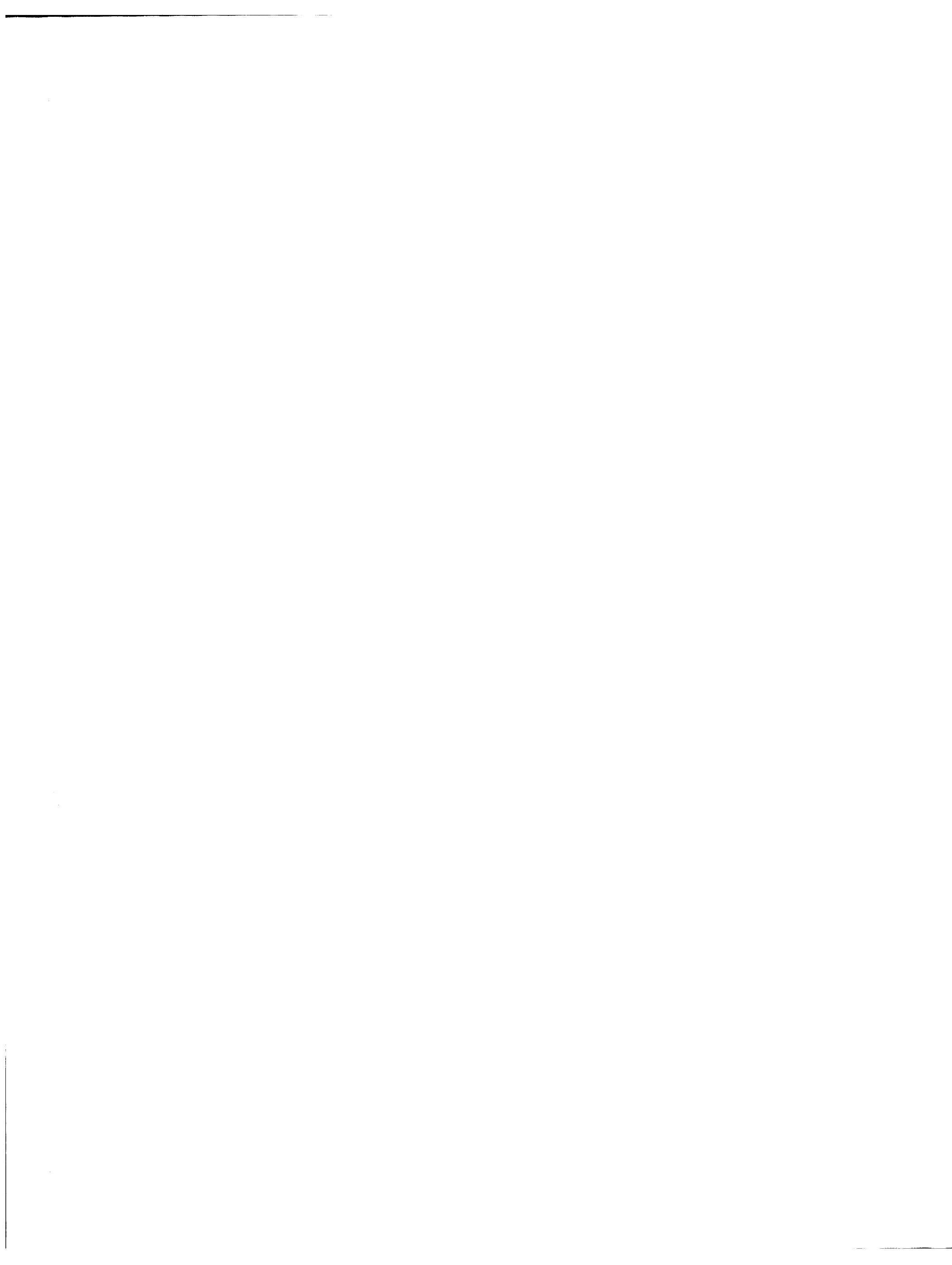